\title{
Cellular and Molecular Targets of Menthol Actions
}

\author{
Murat Oz ${ }^{1,2 *}$, Eslam G. El Nebrisi ${ }^{1}$, Keun-Hang S. Yang ${ }^{3}$, Frank C. Howarth ${ }^{4}$ and \\ Lina T. Al Kury ${ }^{5}$ \\ ${ }^{1}$ Department of Pharmacology, College of Medicine and Health Sciences, United Arab Emirates University, Al Ain, \\ United Arab Emirates, ${ }^{2}$ Department of Basic Medical Sciences, College of Medicine, Qatar University, Doha, Qatar, \\ ${ }^{3}$ Department of Biological Sciences, Schmid College of Science and Technology, Chapman University, Orange, CA, \\ United States, ${ }^{4}$ Department of Physiology, College of Medicine and Health Sciences, United Arab Emirates University, Al Ain, \\ United Arab Emirates, ${ }^{5}$ Department of Health Sciences, College of Natural and Health Sciences, Zayed University, Abu \\ Dhabi, United Arab Emirates
}

\section{OPEN ACCESS}

Edited by:

Giovanni Li Volti,

University of Catania, Italy

Reviewed by:

Antonio Ferrer-Montiel,

Universidad Miguel Hernández de

Elche, Spain

Robert M. Caudle,

University of Florida, United States

Stefan Mergler

Charité Universitätsmedizin Berlin,

Germany

*Correspondence:

Murat $\mathrm{Oz}$

murat.oz@qu.edu.qa

Specialty section:

This article was submitted to

Experimental Pharmacology and Drug

Discovery,

a section of the journal

Frontiers in Pharmacology

Received: 22 March 2017

Accepted: 03 July 2017

Published: 18 July 2017

Citation:

Oz M, El Nebrisi EG, Yang K-HS, Howarth FC and Al Kury LT (2017)

Cellular and Molecular Targets of Menthol Actions.

Front. Pharmacol. 8:472.

doi: 10.3389/fphar.2017.00472
Menthol belongs to monoterpene class of a structurally diverse group of phytochemicals found in plant-derived essential oils. Menthol is widely used in pharmaceuticals, confectionary, oral hygiene products, pesticides, cosmetics, and as a flavoring agent. In addition, menthol is known to have antioxidant, anti-inflammatory, and analgesic effects. Recently, there has been renewed awareness in comprehending the biological and pharmacological effects of menthol. TRP channels have been demonstrated to mediate the cooling actions of menthol. There has been new evidence demonstrating that menthol can significantly influence the functional characteristics of a number of different kinds of ligand and voltage-gated ion channels, indicating that at least some of the biological and pharmacological effects of menthol can be mediated by alterations in cellular excitability. In this article, we examine the results of earlier studies on the actions of menthol with voltage and ligand-gated ion channels.

Keywords: monoterpenes, voltage-gated ion channels, ligand-gated ion channels, TRP channels, menthol

\section{INTRODUCTION}

Menthol, a naturally occurring cyclic monoterpene alcohol of plant origin, gives plants of the Mentha species their distinctive smell and flavor. In Japan for more than 2,000 years, peppermint plant, the main source of menthol, has been cultivated for medicinal purposes (Patel et al., 2007). Menthol is also an important constituent of essential oils such as eucalyptus, lemongrass, and palmarosa. In the present day, menthol is widely used in oral hygiene products, confectionary, pharmaceuticals, cosmetics, pesticides, and as a flavoring agent. With regards to its medicinal purposes, both prescribed and over-the-counter menthol containing medications are currently available for a host of conditions, including respiratory diseases, gastrointestinal disorders, common cold, and musculoskeletal pain (Eccles, 1994; Patel et al., 2007). In addition, it is commonly used as part of analgesic, antiseptic, topical antipruritic, and cooling formulations. It is estimated that $\sim 30,000$ metric tons of menthol are consumed annually (Kamatou et al., 2013). After citrus and vanilla, menthol is one of the most important flavoring substances in culinary industry. It is also a commonly used compound in many tobacco products. The estimated use

Abbreviations: ACh, Acetylcholine; AP, Action potential; CAP, Compound action potential; CNS, Central nervous system; DRG, Dorsal root ganglion; GABA, Gamma-aminobutyric acid; GPCR, G-protein coupled receptor; VGIC, Voltage-gated ion channel; LGIC, Ligand-gated ion channel; TRP, Transient-receptor potential; TTX, Tetrodotoxin; VGCC, Voltage-gated calcium channel; VGSC, Voltage-gated sodium channel. 
pattern for L-menthol at the beginning of twenty-first century is as follows: $36 \%$ oral care products, $22 \%$ pharmacy products, $19 \%$ tobacco products, $17 \%$ flavors, $6 \%$ others (OECD, 2003). Despite menthol's use since antiquity, the mechanisms mediating its pharmacological actions remain relatively unknown. The focus of this report is to highlight the recent advances in the menthol research and to provide an overview of its actions on cellular excitability.

Menthol [5-methyl-2-(1-methylethyl) cyclohexanol; 2isopropyl-5-methylcyclohexanol or p-methan-3-ol], with the molecular formula $\mathrm{C} 10 \mathrm{H} 20 \mathrm{O}$ (MW. 156.27), is a natural compound with three asymmetric carbon atoms and, thus, occurs as four pairs of optical isomers namely, $(+)$ - and (-)-menthol, $(+)$ - and (-)-neomenthol, (+)- and (-)-neoisomenthol, and $(+)$ - and (-)-isomenthol (Figure 1). The major form of menthol found in nature is $(-)$-menthol (L-menthol). (-)-Menthol is frequently employed since it retains better cooling properties than the other isomers (Figure 1). Menthol is a colorless or white, crystalline, and flaky substance. Depending on its purity, menthol has a melting point of $41-44^{\circ} \mathrm{C}$ and it is solid at room temperature $\left(25^{\circ} \mathrm{C}\right)$ with a density of $0.890 \mathrm{~g} / \mathrm{cm}^{3}$. It is not completely soluble in water $\left(431 \mathrm{mg} / \mathrm{L}\right.$ at $\left.20^{\circ} \mathrm{C}\right)$, but freely soluble in chloroform, diethyl ether, and alcohol (Kamatou et al.,

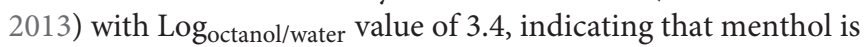
a lipophilic compound capable of interacting with membranes (Turina et al., 2006).

All menthol isomers are absorbed well through oral route of exposure and are excreted mainly as glucuronides. In rats, an extensive enterohepatic circulation additionally leads to various hydroxylated degradation products. Main elimination pathway for glucuronides and degradation products is via urine; however, small quantities are removed via feces. For all isomers of menthol, a very low acute oral toxicity with $\mathrm{LD}_{50}$ values normally greater than $2,000 \mathrm{mg} / \mathrm{kg}$ bw has been reported. In an earlier report, rats receiving diets with up to $200 \mathrm{mg} / \mathrm{kg}$ bw/d of menthol for 5.5 weeks showed no signs of toxicity (National Toxicology Program, 1979; OECD, 2003).

\section{EFFECTS OF MENTHOL ON ION CHANNELS}

Ion channels are pore-forming integral membrane proteins that regulate the transfer of charged ions $\left(\mathrm{Ca}^{2+}, \mathrm{K}^{+}, \mathrm{Na}^{+}\right.$, or $\mathrm{Cl}^{-}$) through the bilayer membrane of the cell and regulate resting membrane potential, action potentials and other electrical signals. Channel opening is usually triggered by a specific stimulus such as membrane depolarization, mechanical stretch, or binding to a ligand. Ionic currents produced by the passage of ions through these channels constitutes the electrophysiological origin for several cellular events including the release of neurotransmitters, muscle contraction, cell development, secretion of hormones, various transmembrane signaling processes, and excitation-transcription coupling (Cannon et al., 2014; Tien et al., 2014). It is known that several chemicals demonstrate their therapeutic actions by influencing the functions of ion channels in different types of cells. In recent years, there has been considerable interest in pharmacological targets of menthol. Actions of menthol on various ion channels have been reported in several recent investigations. The results of some of these recent studies will be reviewed in the following sections (Table 1).

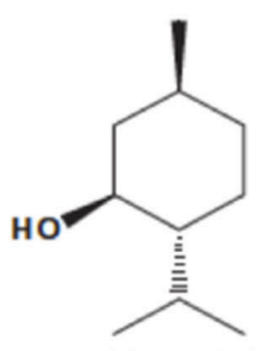

(+)-Menthol

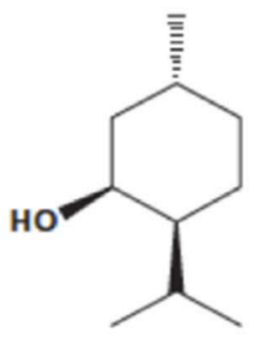

(+)-Neomenthol

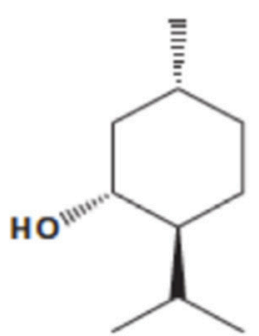

(-)-Menthol

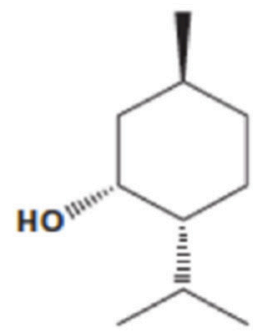

(-)-Neomenthol<smiles>CC(C)[C@H]1CC[C@@H](C)C[C@H]1O</smiles>

(+)-Isomenthol<smiles>CC(C)[C@H]1CC[C@@H](C)C[C@H]1O</smiles>

(+)-Neoisomenthol<smiles>CC(C)[C@H]1CC[C@@H](C)C[C@H]1O</smiles>

$(-)$-Isomenthol

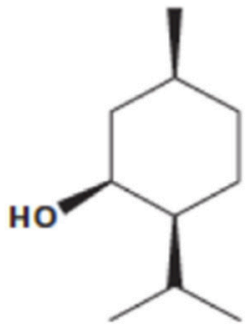

$(-)$-Neoisomenthol

FIGURE 1 | Structure of menthol isomers (from left to right, top row): (+)-Menthol, (-)-Menthol, (+)-Isomenthol, (-)-Isomenthol, (+)-Neomenthol, (-)-Neomenthol, (+)-Neoisomenthol, (-)-Neoisomenthol. 
TABLE 1 | Summary of cellular and molecular effects of menthol.

\begin{tabular}{|c|c|c|c|c|c|}
\hline Target protein or cellular event & $\begin{array}{l}\text { End-point } \\
\text { measured }\end{array}$ & Effect & Concentration and ligand & Preparation & References \\
\hline $\mathrm{Na}^{+}$channels & Ion current & Inhibition & $\begin{array}{l}\mathrm{IC}_{50}=376 \mu \mathrm{M} \text { (In neuronal } \mathrm{Na}^{+} \\
\text {channels) } \\
\mathrm{IC}_{50}=571 \mu \mathrm{M} \text { (In skeletal } \\
\text { muscle } \mathrm{Na}^{+} \text {channels) }\end{array}$ & HEK293 cells & Haeseler et al., 2002 \\
\hline $\mathrm{Na}^{+}$channels & Ion current & Inhibition & $\mathrm{IC}_{50}=297 \mu \mathrm{M}$ & Cultured dorsal horn neurons & Pan et al., 2012 \\
\hline TTX-resistant $\mathrm{Na}^{+}$channels & Ion current & Inhibition & $\mathrm{IC}_{50}=299-500 \mu \mathrm{M}$ & $\begin{array}{l}\text { DRG neurons and immortalized } \\
\text { DRG neuron-derived F11 cells }\end{array}$ & Gaudioso et al., 2012 \\
\hline Nav1.8 channel subtype & & & $\begin{array}{l}>300 \mu \mathrm{M} \\
540-807 \mu \mathrm{M}\end{array}$ & & \\
\hline \multicolumn{6}{|l|}{ Nav1.9 channel subtype } \\
\hline $\mathrm{Na}^{+}$channels & $\begin{array}{l}\text { Compound action } \\
\text { potential }\end{array}$ & Inhibition & $\begin{array}{l}\mathrm{I}_{50}=1.1 \mathrm{mM}(-) \text {-menthol } \\
\mathrm{IC}_{50}=0.9 \mathrm{mM}(+) \text {-Menthol }\end{array}$ & Frog sciatic nerve fibers & Kawasaki et al., 2013 \\
\hline $\mathrm{Na}^{+}$channels & $\begin{array}{l}\text { Number and } \\
\text { duration of action } \\
\text { potential bursts }\end{array}$ & Inhibition & $250 \mu \mathrm{M}$ & Mouse cortical neurons & Pezzoli et al., 2014 \\
\hline $\begin{array}{l}\text { DHP-sensitive and } \\
\text { DHP-insensitive } \mathrm{Ca}^{2+} \text { channels }\end{array}$ & Ion current & Inhibition & $\mathrm{IC}_{50}=0.25 \mathrm{mM}$ & LA-N-5 cells & Sidell et al., 1990 \\
\hline $\mathrm{Ca}^{2+}$ channels & $\begin{array}{l}\text { High } \mathrm{K}^{+} \text {-induced } \\
\text { intracellular } \mathrm{Ca}^{2+} \\
\text { increase }\end{array}$ & Inhibition & $2 \mathrm{mM}$ & Leech neurons & Dierkes et al., 1997 \\
\hline \multirow[t]{2}{*}{$\mathrm{Ca}^{2+}$ channels } & $\begin{array}{l}\mathrm{Ca}^{2+} \text { uptake and } \\
\text { contractile } \\
\text { response }\end{array}$ & Inhibition & $\mathrm{IC}_{50}=8-28 \mu \mathrm{g} / \mathrm{ml}$ & Ilium & Hawthorn et al., 1988 \\
\hline & & & $\mathrm{IC}_{50}=10-69 \mu \mathrm{g} / \mathrm{ml}$ & $\begin{array}{l}\text { Cardiac tissue synaptosomes } \\
\text { and chick retinal neurons }\end{array}$ & \\
\hline \multirow[t]{3}{*}{$\mathrm{Ca}^{2+}$ channels } & $\begin{array}{l}\mathrm{KCl} \text {-preconstricted } \\
\text { smooth muscle } \\
\text { contraction }\end{array}$ & Inhibition & $\mathrm{IC}_{50}=58 \mu \mathrm{M}$ & Bronchial smooth muscle fibers & Wright et al., 1997 \\
\hline & & & $\mathrm{IC}_{50}=120 \mu \mathrm{M}$ & & \\
\hline & $\begin{array}{l}\text { ACh- } \\
\text { preconstricted } \\
\text { smooth muscle } \\
\text { contraction }\end{array}$ & & & & \\
\hline $\mathrm{Ca}^{2+}$ channels & Intracellular $\mathrm{Ca}^{2+}$ & Inhibition & $0.01-1 \mathrm{mM}$ & Tracheal smooth muscle fibers & $\begin{array}{l}\text { Ito et al., 2008; Wang } \\
\text { et al., } 2016\end{array}$ \\
\hline $\mathrm{Ca}^{2+}$ channels & Intracellular $\mathrm{Ca}^{2+}$ & Inhibition & $300 \mu \mathrm{M}$ & Detrusor muscle & $\begin{array}{l}\text { Ramos-Filho et al., } \\
2014\end{array}$ \\
\hline $\mathrm{Ca}^{2+}$ channels & Intracellular $\mathrm{Ca}^{2+}$ & Inhibition & $0.1-1 \mathrm{mM}$ & Vas deference & $\begin{array}{l}\text { Filippov et al., 2009; } \\
\text { Vladymyrova et al., } \\
2011\end{array}$ \\
\hline $\mathrm{Ca}^{2+}$ channels & $\begin{array}{l}\mathrm{Ca}^{2+} \text { influx and } \\
\text { smooth muscle } \\
\text { relaxation }\end{array}$ & Inhibition & $0.1-1 \mathrm{mM}$ & $\begin{array}{l}\text { Rat aorta, mesenteric and } \\
\text { coronary arteries }\end{array}$ & Cheang et al., 2013 \\
\hline $\mathrm{Ca}^{2+}$ channels & $\begin{array}{l}\mathrm{Ca}^{2+} \text { influx and } \\
\text { contraction }\end{array}$ & Inhibition & $0.1-30 \mathrm{mM}$ & $\begin{array}{l}\text { Gastrointestinal smooth muscle } \\
\text { and human colon circular muscle }\end{array}$ & Amato et al., 2014a \\
\hline \multirow[t]{3}{*}{$\mathrm{Ca}^{2+}$ channels } & $\begin{array}{l}\text { High } \mathrm{K}^{+} \text {and } \\
\mathrm{Ca}^{2+} \text { evoked } \\
\text { contractions }\end{array}$ & Inhibition & $\mathrm{IC}_{50}=22.1 \mu \mathrm{g} / \mathrm{mL}$ & Guinea pig taenia coli & $\begin{array}{l}\text { Hills and Aaronson, } \\
1991\end{array}$ \\
\hline & & & $\mathrm{IC}_{50}=25.9 \mu \mathrm{g} / \mathrm{mL}$ & Guinea pig colon & \\
\hline & & & $\mathrm{IC}_{50}=15.2 \mu \mathrm{g} / \mathrm{mL}$ & Rabbit jejunum & \\
\hline $\mathrm{Ca}^{2+}$ channel & $\mathrm{Ca}^{2+}$ current & Inhibition & $0.1-0.5 \mathrm{mM}$ & Helix neurons & Swandulla et al., 1986 \\
\hline $\begin{array}{l}\text { Low voltage-activated } \mathrm{Ca}^{2+} \\
\text { channel (T-type like) and high } \\
\text { voltage activated } \mathrm{Ca}^{2+} \text { channel } \\
\text { (L-type like) }\end{array}$ & $\mathrm{Ca}^{2+}$ current & Inhibition & $0.1-1 \mathrm{mM}$ & Cultured DRG neurons & Swandulla et al., 1987 \\
\hline L-type VGCCs & $\mathrm{Ca}^{2+}$ current & Inhibition & $I_{50}=74.6$ & Rabbit ventricular myocyte & Baylie et al., 2010 \\
\hline TRPM8 & $\mathrm{Ca}^{2+}$ current & Activation & $300 \mu \mathrm{M}$ & Rat tail artery myocytes & Melanaphy et al., 2016 \\
\hline
\end{tabular}


TABLE 1 | Continued

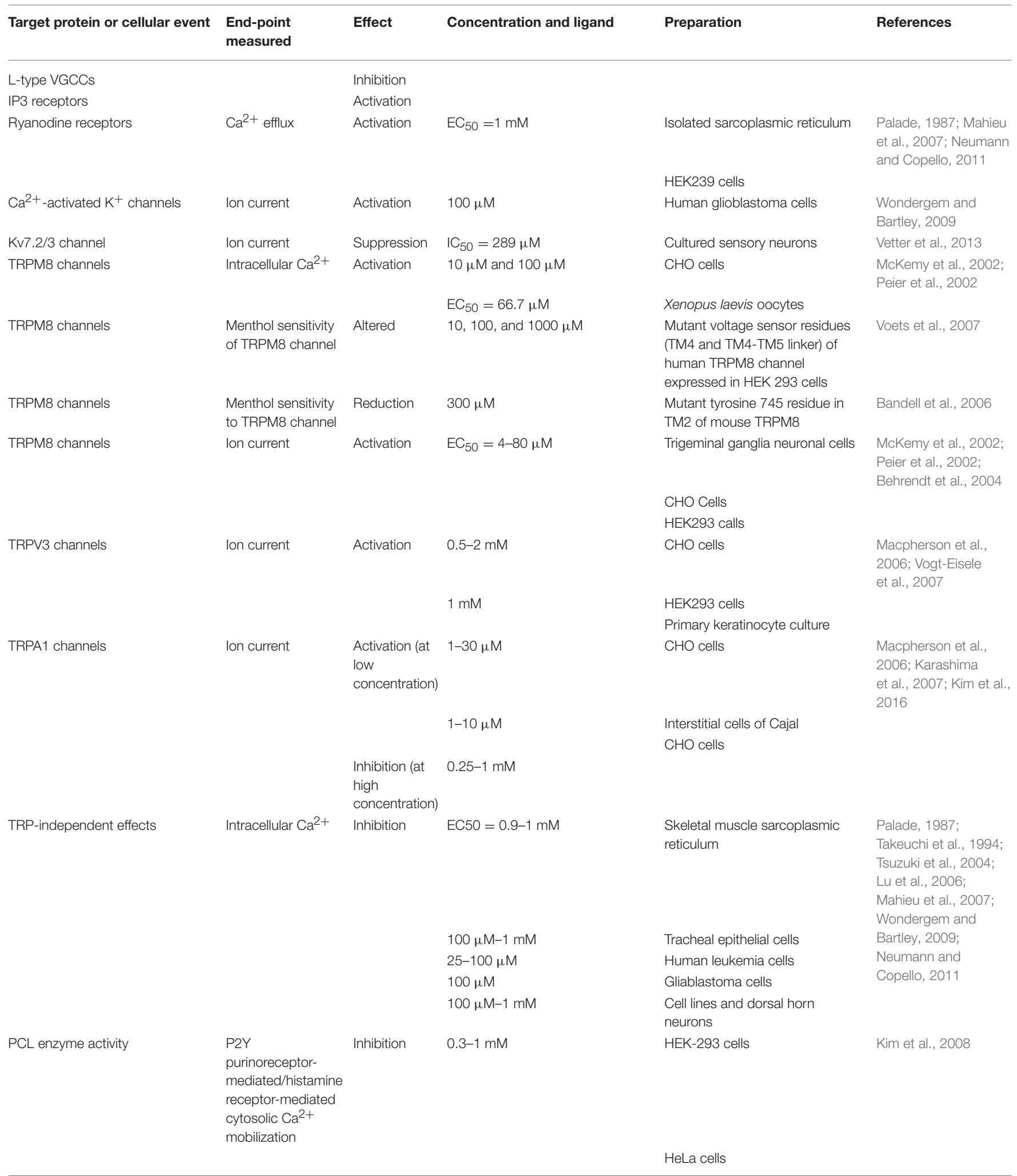


TABLE 1 | Continued

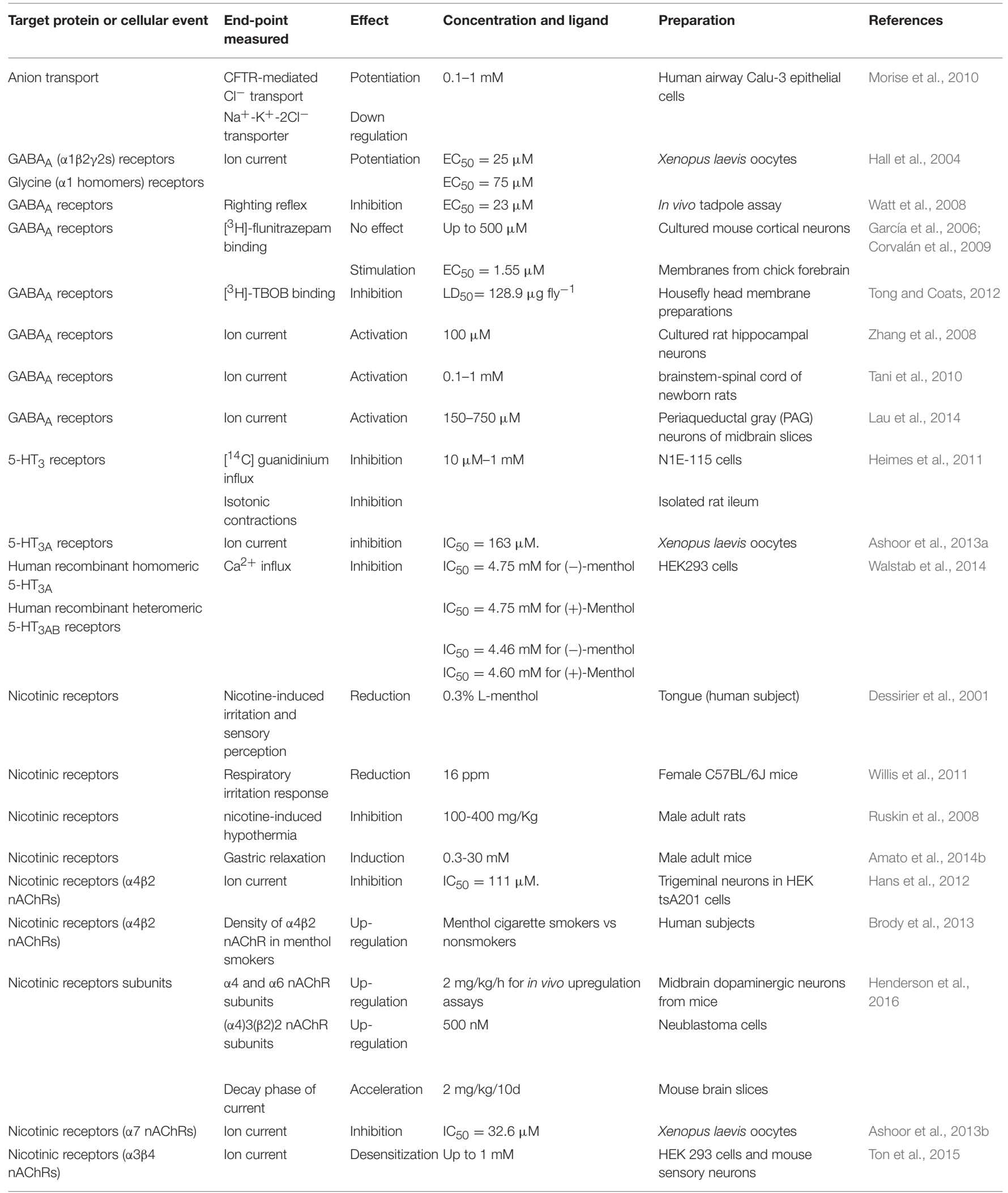




\section{Voltage-Gated Sodium Channels}

Voltage-gated sodium channels (VGSCs) have essential roles in the generation and propagation of action potentials (APs) in excitable cells including neurons, cardiomyocytes, smooth muscle cells, and skeletal muscle fibers (Savio-Galimberti et al., 2012; Peters and Ruben, 2014). VGSCs are stimulated by the changes in membrane potential. The depolarizing changes are detected by a voltage sensor connected to the pore domain that opens and allows the influx of sodium. Local anesthetics, antinociceptive, antiarrhythmic, and antiepileptic drugs antagonize the functions of ion channels by binding to a specific site located on the protein structure, whereas other classes of chemicals and neurotoxins bind to distinct receptor sites within the pore of the channel (for a review, Catterall et al., 2013).

Various over-the-counter products for pain relief and topical balms often contain menthol in the concentrations ranging from 5 to $16 \%(320-1,024 \mathrm{mM})$. In this concentration range, topical application of menthol has been shown to be antinociceptive for heat and cold-induced pain (Green, 1986; Albin et al., 2008; Klein et al., 2010, 2012). Menthol has also been shown to have anti-nociceptive actions in the mouse abdominal constriction and hot-plate tests (Galeotti et al., 2002). Antinociceptive actions of menthol were stereo-selective, since only (-) enantiomer was active in in vivo models. Local anesthetic activity of menthol has also been demonstrated in earlier studies (Galeotti et al., 2001). However, both (-) and (+) isomers of menthol are equally active in their local anesthetic actions.

The effect of menthol on sodium channels was tested in an earlier patch-clamp study (Haeseler et al., 2002) in HEK293 cells transfected with human skeletal muscle and rat neuronal VGSCs. Menthol suppressed whole cell $\mathrm{Na}^{+}$ currents with an $\mathrm{IC}_{50}$ value of 571 and $376 \mu \mathrm{M}$ for neuronal cells and skeletal muscle fibers, respectively. The strength of menthol effects enhanced significantly at depolarized potentials with increasing portion of inactivated channels, suggesting that preferential blockade of VGSC in inactivated state may mediate antinociceptive and local anesthetic effects of menthol (Haeseler et al., 2002). In another electrophysiological study, Gaudioso et al. (2012), using whole-cell patch clamp method, investigated the actions of menthol on tetrodotoxin (TTX)sensitive VGSCs in immortalized dorsal root ganglia (DRG) neuron-derived F11 cells and on TTX-resistant Nav1.9 and Nav1.8 channel subtypes in DRG neurons, and (Gaudioso et al., 2012). It was found that VGSCs were suppressed by menthol in a concentration, frequency, and voltage-dependent manner. Firing at high-frequency stimulation was suppressed by menthol while minimal effect was observed on normal neuronal activity recorded by current clamp technique. In addition, menthol at low concentrations caused analgesia and relieved pain produced by a $\mathrm{Na}^{+}$channel-targeting toxin in mice. In conclusion, the results of this study indicated that Nav1.8, Nav1.9, and TTXsensitive $\mathrm{Na}^{+}$channels are blocked by menthol in a state-selective manner suggesting a role for $\mathrm{Na}^{+}$channel blockade in the efficacy of menthol as topical analgesic compound (Gaudioso et al., 2012).
Menthol, by dose-dependently diminishing both contralateral and ipsilateral pain hypersensitivity produced by complete Freund's adjuvant, showed direct effects on the spinal cord (Pan et al., 2012). In addition, both first and second stages of formalin-induced spontaneous nocifensive behavior were attenuated by menthol. In cultured dorsal horn neurons, menthol inhibited VGSCs in a state-, use-, and voltage-dependent manner. Moreover, menthol inhibited repetitive firing and the amplitudes of action potentials, inhibited spontaneous synaptic transmission and decreased excitability in cultured superficial dorsal horn neurons. The examination of brain menthol concentrations showed that, when applied systemically, menthol is rapidly accumulated in the brain tissue (Pan et al., 2012), suggesting that this compound induces analgesic effect on inflammatory pain models via inhibition of VGSCs in the central nervous system. In another study (Kawasaki et al., 2013), both (-) and (+)-menthol concentration-dependently decreased the peak amplitudes of compound action potentials (CAPs) with the $\mathrm{IC}_{50}$ values of 1.1 and $0.93 \mathrm{mM}$, respectively. (-)-menthone and (+)-menthone also suppressed CAPs with extents similar to that of menthol (Kawasaki et al., 2013).

A recent study in mouse cortical neurons (Pezzoli et al., 2014) reported that menthol $(250 \mu \mathrm{M})$ dampens the generation of action potentials in a time- and voltage-dependent manner in TRPM8 knock-out mice and in the presence of a TRPM8 blocker. The effects of menthol were also studied on seizures induced by in vitro gabazine applications. Menthol decreased the duration and the number of action potential bursts. In addition, an increase in the concentration of gabazine was needed to elicit seizures. The results suggest that menthol can modulate VGSCs of cortical neurons in the brain through a TRP-independent pathway (Pezzoli et al., 2014).

\section{Voltage-Gated Calcium Channels}

Voltage-gated $\mathrm{Ca}^{2+}$ channels (VGCCs) are required for key functions in excitable cell. (Hofmann et al., 2014; Simms and Zamponi, 2014). The opening of VGCCs by changes in membrane depolarization causes rapid increases in cytoplasmic $\mathrm{Ca}^{2+}$ concentration. Elevated $\mathrm{Ca}^{2+}$ levels can trigger key cellular events such as contraction, exocytosis, gene transcription, and excitability (Badou et al., 2013; Bannister and Beam, 2013; Reuter et al., 2013).

Several earlier reports have demonstrated that menthol modulates the functional properties of VGCCs. In LA-N-5 cells, brief application of menthol inhibited the depolarizationinduced $\mathrm{Ca}^{2+}$ influx though both dihydropyridine-sensitive and -insensitive L-type $\mathrm{Ca}^{2+}$ channels with $\mathrm{IC}_{50}$ value of $0.25 \mathrm{mM}$ (Sidell et al., 1990). $\mathrm{Ca}^{2+}$ increases induced by high $\mathrm{K}^{+}$were suppressed by menthol in Leech neurons (Dierkes et al., 1997), chick retinal neurons and synaptosomes (Hawthorn et al., 1988). It was shown that menthol suppresses high $\mathrm{K}^{+}$-elicited and electrically stimulated contractile responses in atrial and papillary muscles and in ileum. $\mathrm{IC}_{50}$ values in the ileum tissue ranged from 8 to $28 \mu \mathrm{g} / \mathrm{ml}$ and in the cardiac preparations from 10 to $69 \mu \mathrm{g} / \mathrm{ml}$. Notably, menthol acts as a competitive inhibitor on the specific binding of $\left[{ }^{3} \mathrm{H}\right] \mathrm{PN} 200-110$ and $\left[{ }^{3} \mathrm{H}\right]$ nitrendipine, dihydropyridine class antagonists of L-type $\mathrm{Ca}^{2+}$ 
channels in cardiac and smooth muscles and neuronal tissue with potencies similar to those determined in earlier studies (Hawthorn et al., 1988). In tracheal (Ito et al., 2008) and bronchial (Wright et al., 1997) smooth muscle fibers, vas deference (Filippov et al., 2009; Vladymyrova et al., 2011), and detrusor muscle (Ramos-Filho et al., 2014), menthol decreased the KCland ACh-induced muscle contractures by inhibiting of L-type VGCCs. Recent study in tracheal smooth muscle preparation reported that methacholine and electrical field stimulation induced contractions were suppressed significantly by menthol and suggested that VGCCs were affected by this compound (Wang et al., 2016).

Consistent with earlier findings, menthol was demonstrated to cause relaxation and suppress contraction in coronary and mesenteric arteries, and rat aorta (Cheang et al., 2013), mainly by decreasing the influx of $\mathrm{Ca}^{2+}$ via dihydropyridine-sensitive L-type VGCCs. In addition, menthol (0.1-30 mM) inhibited the contractility of the gastrointestinal smooth muscle and induced spasmolytic effects in human colon circular muscle by inhibiting the entrance of $\mathrm{Ca}^{2+}$ through L-type VGCCs (Amato et al., 2014a). Peppermint oil has also been shown to reduce the contractions evoked by high $\mathrm{K}^{+}$and $\mathrm{Ca}^{2+}$ in guinea pig taenia coli by inhibiting L-type VGCCs (Hills and Aaronson, 1991).

Several electrophysiological studies investigated the effects of menthol on currents mediated by VGCCs. In a previous investigation, the effects of menthol $(0.1-0.5 \mathrm{mM})$ on the inactivation of $\mathrm{Ca}^{2+}$ currents were examined in Helix neurons (Swandulla et al., 1986). Although internal application was ineffective, external application of menthol caused acceleration of inactivation during $\mathrm{Ca}^{2+}$-dependent rapid phase. In following experiments, the actions of menthol on $\mathrm{Ca}^{2+}$ current were examined in cultured DRG neurons from embryos of rat and chick (Swandulla et al., 1987). Bath application of menthol (0.1$1 \mathrm{mM}$ ) caused various types of effects on different kinds of $\mathrm{Ca}^{2+}$ currents in these neurons. Below membrane potential of -20 $\mathrm{mV}$, menthol suppressed the amplitudes of low threshold ( $\mathrm{T}$ type like) $\mathrm{Ca}^{2+}$ currents in a dose-dependent fashion; with no alteration of activation kinetics. On the other hand, externally applied menthol significantly accelerated the inactivation of the L-type (high-threshold) $\mathrm{Ca}^{2+}$ currents (activated from a holding potential of $-80 \mathrm{mV}$ to positive potentials above $-20 \mathrm{mV}$ ). The effects of menthol remained unaltered at holding potentials more positive than $-20 \mathrm{mV}$. Importantly, the effect of menthol was observed only when it was applied from the outside. Together, findings of this investigation showed that menthol inhibits $\mathrm{Ca}^{2+}$ influx through the low voltage-activated $\mathrm{Ca}^{2+}$ channel, and enhances the inactivation of the L-type (high voltage-activated) $\mathrm{Ca}^{2+}$ channel.

Succeeding these investigations in neurons, the effects of menthol on L-type VGCCs of rabbit ventricular myocyte was studied using whole-cell recording technique at nearphysiological temperature $\left(\sim 35^{\circ} \mathrm{C}\right)$ (Baylie et al., 2010). Menthol inhibited peak amplitudes of $\mathrm{Ca}^{2+}$ currents in a concentrationdependent manner with an $\mathrm{IC}_{50}$ value of $74.6 \mu \mathrm{M}$. The late currents remaining at the end of depolarizing pulses were also suppressed by menthol. Menthol inhibited these late currents with greater efficacy ( $96 \%$ block at $1 \mathrm{mM})$ than peak (68\% block at $1 \mathrm{mM}$ ) $\mathrm{Ca}^{2+}$ currents (Baylie et al., 2010). Similarly, inhibition of L-type VGCCs by menthol has also been shown in smooth muscle cells (Melanaphy et al., 2016).

The effects of menthol are not limited to $\mathrm{Ca}^{2+}$ influx through VGCCs. Menthol has significant effect on other components of $\mathrm{Ca}^{2+}$ homeostasis as well. For example, it has been shown that (Mahieu et al., 2007; Wondergem and Bartley, 2009; Neumann and Copello, 2011; Melanaphy et al., 2016), menthol induces $\mathrm{Ca}^{2+}$ release from intracellular stores. In addition, menthol has been shown to induce activation of IP3 receptors (Melanaphy et al., 2016), and RyR1 ryanodine receptors with an approximate EC $_{50}$ of $1 \mathrm{mM}$ (Palade, 1987; Neumann and Copello, 2011). Thus, it is likely that some of the menthol actions are due to enhancement of $\mathrm{Ca}^{2+}$-induced inactivation of VGCCs and/or activations of second messenger pathways as a result of alteration in intracellular $\mathrm{Ca}^{2+}$ levels.

\section{Voltage-Gated Potassium Channels}

Voltage-gated $\mathrm{K}^{+}$channels (VGKCs) are important membrane proteins embedded into lipid bilayer membrane. Stimulation of VGKCs by depolarizing membrane potentials leads to opening of these channels and causes the hyperpolarization of excitable cells. The VGKCs are broadly distributed throughout the mammalian tissues and play vital roles in dampening cellular excitability under several pathological and physiological conditions (Maljevic and Lerche, 2013; Tian et al., 2014). Some of the physiological functions of $\mathrm{K}^{+}$channels include determining the action potential duration, changing the interspike intervals during repetitive firing of the heart and neurons, secreting $\mathrm{K}^{+}$ in epithelial tissue, and causing smooth muscle contractions (Maljevic and Lerche, 2013; Tian et al., 2014). These channels are composed of four subunits, gathered in the cell membranes as tetrameric structures. Due to the large number of different genes present, auxiliary $\beta$-subunits and metabolic regulation, there is considerable functional diversity among different subtypes (González et al., 2012; Latorre et al., 2013).

Data on the effect of menthol on $\mathrm{K}^{+}$channels are rather limited. In human glioblastoma cells, $\mathrm{Ca}^{2+}$-activated $\mathrm{K}^{+}$currents were demonstrated to be stimulated by menthol (Wondergem and Bartley, 2009). Recently, using a dye sensitive to membrane potential, menthol was reported to suppress Kv7.2/3 channel subtypes that produce the $\mathrm{M}$-current in neurons with $\mathrm{IC}_{50}$ value of $289 \mu \mathrm{M}$ (Vetter et al., 2013). However, further investigations are needed to assess the importance of menthol as a modulator of VGKCs in various cell types.

\section{Transient Receptor Potential Channels}

Transient Receptor Potential (TRP) superfamily of non-selective cation channels are encoded by more than 30 distinct genes in mammals and play important roles in sensory physiology, which include contributions to thermo- and osmosensation, vision, touching, olfaction, taste, and hearing (Nilius and Szallasi, 2014). TRP channels have tetrameric structures formed by six transmembrane domain subunits and cation-selective pores, which usually show high permeability to calcium (Latorre et al., 2009). TRP channels in mammalian cells are composed of seven families of related proteins: TRPM (melastatin), TRPA 
(ankyrin-like), TRPV (vanilloid), TRPC (classical or canonical), TRPN (no mechanoreceptor potential C) TRPML (mucolipin), and TRPPP (polycysteine) (Clapham and Squire, 2009; Gees et al., 2012; Nilius and Szallasi, 2014). In addition to sensory physiology, these channels play diverse functional roles ranging from modification of growth cone morphology to intracellular $\mathrm{Ca}^{2+}$ homeostasis (Freichel and Flockerzi, 2007; Julius, 2013; Nilius and Appendino, 2013; Billeter et al., 2014). Importantly, majority of TRP channels function as polymodal sensors. These channels are activated by physical stimuli such as stretch, osmotic pressure, membrane voltage, and temperature as well as chemical stimuli, fatty acids and other membrane lipids (Bradshaw et al., 2013). Besides direct activation by physical stimuli, unliganded TRP channels can also be stimulated by G-protein coupled receptors (Veldhuis et al., 2015) and receptor tyrosine kinases (Nilius and Szallasi, 2014).

Menthol, in the concentrations ranging from $10 \mu \mathrm{M}$ to 1 $\mathrm{mM}$, has been reported to stimulate TRPM8 receptors (McKemy et al., 2002; Peier et al., 2002). Intracellular $\mathrm{Ca}^{2+}$ levels have been shown to be elevated by menthol in a concentrationdependent manner in HEK293 and CHO cells overexpressing TRPM8. Patch-clamp experiments in sensory neurons have demonstrated that activation of TRPM8 receptors induces outwardly rectifying, $\mathrm{Ca}^{2+}$ permeable cation currents that show strong resemblances to the endogenous menthol- and coldactivated currents (McKemy et al., 2002; Peier et al., 2002). An examination of the voltage dependence of currents mediated by TRPM8 receptors showed that cold and menthol employ the similar mechanism to activate this channel. It appears that both menthol and cold shift the voltage-dependent activation curve of TRPM8 to more physiological potentials (Voets et al., 2004).

Structures of TRP channels are tetrameric and composed of four subunits containing six transmembrane segments (TM1TM6). Mutation of residues sensitive to potential changes in the TM4 and the TM4-TM5 linker effects menthol- and coldsensitivity of TRPM8 receptors (Voets et al., 2007). Random mutagenesis screening studies indicated that tyrosine 745 , located in the middle of putative transmembrane segment 2, is as a crucial amino acid residue for the menthol sensitivity of mouse TRPM8 receptor (Bandell et al., 2006). Receptorchannel complex that contains TRPM8-Y745H mutation was found to be not sensitive to menthol, but retained the voltage and cold sensitivity of the wild-type channel. In another study, it was proposed that single TRPM8 channel can independently bind up to four menthol molecules, and that bound menthol molecules cause a similar energetic stabilization of the open channel (Janssens and Voets, 2011). Menthol sensitivity of TRPM8 receptors has also been shown to be influenced by posttranslational modifications such as glycosylation (Pertusa et al., 2012). It seems that reduction of TRPM8 glycosylation causes a significant decrease in the menthol responsiveness of TRPM8 receptor (Pertusa et al., 2012). Another feature that appears to influence sensitivity of TRPM8 receptors to menthol is the bilayer lipid structure of the plasma membranes. Interestingly, disturbance by methyl- $\beta$-cyclodextrin of lipid rafts has been demonstrated to increase stimulation of TRPM8 receptors by menthol (Morenilla-Palao et al., 2009).
Notably, the interaction between menthol and TRPM8 receptor is not limited to excitable cells. Various non-excitable cancer cells expressing TRPM8 receptors has also been shown to be affected by menthol. For example, menthol has been shown to inhibit growth of human melanoma cells via activation of TRPM8 receptors (Slominski, 2008; Yamamura et al., 2008). Similarly, menthol has been reported to induce cell death via the TRPM8 receptor in the human bladder cancer cell line T24 ( $\mathrm{Li}$ et al., 2009) indicating that menthol modulation of TRPM8 receptors may have some clinical implications as well.

Besides menthol, in the concentrations ranging from 100 $\mu \mathrm{M}$ to $10 \mathrm{mM}$, many monoterpenes with structures similar to menthol, including carvone, isopulegol, and euganol (Bandell et al., 2004), linalool, geraniol, eucalyptol, citronellal (Behrendt et al., 2004), and menthone (McKemy et al., 2002) also stimulate TRPM8 receptors (for a review Oz et al., 2015). However, actions of these compounds, compared to menthol, are less described and it is not clear if they utilize the same binding site as menthol on the TRPM8 receptor.

Among naturally occurring TRP ligands some extent of promiscuity exists. For example, the monoterpene menthol, generally considered a TRPM8-specific agonist, was reported to activate TRPV3 (Macpherson et al., 2006; Vogt-Eisele et al., 2007) and TRPA1 (Karashima et al., 2007) receptors. It appears that menthol in the range of submicromolar to low-micromolar concentrations, causes activation of TRPA1 channel, whereas at higher concentrations menthol leads to a reversible blockade of the channel (Karashima et al., 2007). Menthol has also been shown to induce membrane depolarizations by activating TRPA1 channels in interstitial cells of Cajal (Kim et al., 2016). While activation of TRPM8 by menthol occurs with an $\mathrm{EC}_{50}$ of approximately in the range of 4-80 $\mu \mathrm{M}$ (McKemy et al., 2002; Peier et al., 2002; Behrendt et al., 2004), higher menthol concentrations are required for modulation of other thermosensitive TRP channels.

Earlier studies have also shown TRP channel-independent actions of menthol. In various cell types, including skeletal muscle sarcoplasmic reticulum (Palade, 1987; Neumann and Copello, 2011; $\mathrm{EC}_{50}=0.9-1 \mathrm{mM}$ ), tracheal epithelial cells (Takeuchi et al., 1994; $100 \mu \mathrm{M}-1 \mathrm{mM}$ ) human leukemia cells (Lu et al., 2006; 25 to $100 \mu \mathrm{M}$ ), gliablastoma cells (Wondergem and Bartley, 2009; $100 \mu \mathrm{M}$ ), commonly used cell lines (HEK-293, LNCaP, CHO, and COS, Mahieu et al., 2007; $100 \mu \mathrm{M}-1 \mathrm{mM}$ ) and dorsal horn neurons (Tsuzuki et al., 2004, $100 \mu \mathrm{M}-1 \mathrm{mM}$ ), menthol has been shown to increase intracellular $\mathrm{Ca}^{2+}$ levels independently of TRP-channel activation.

Menthol also directly inhibits the activity of several enzymes (Kim et al., 2008, 2009). In HEK-293 and HeLa cells, menthol, in the concentrations of $0.3-1 \mathrm{mM}$, causes significant inhibition of P2Y purinoceptor-mediated or histamine receptor-mediated cytosolic $\mathrm{Ca}^{2+}$ mobilization (Kim et al., 2008). The results of further biochemical experiments in this study indicated that menthol inhibits the activity of PLC directly. Furthermore, the authors have shown that ADP-stimulated aggregation of human erythrocytes was blocked by menthol, suggesting that menthol can be a clinically useful agent to prevent platelet aggregation. Similarly, in PC-3 cells, phosphorylation of c-jun N-terminal 
kinase (JNK) was significantly potentiated by menthol (Kim et al., 2009).

In human airway Calu-3 epithelial cells that do not express TRPM8 channels, menthol (0.1-1 mM) heterologously regulates anion transport through cAMP-independent mechanisms by potentiating the cystic fibrosis transmembrane conductance regulator (CFTR)- mediated $\mathrm{Cl}^{-}$transport $\left(\mathrm{EC}_{50}=190 \mu \mathrm{M}\right)$ and by down regulating $\mathrm{Na}^{+}-\mathrm{K}^{+}-2 \mathrm{C1}^{-}$transporter activity (Morise et al., 2010). It is concluded that the actions of menthol on actin cytoskeleton which interacts with these anion transporters mediates the observed effects of menthol on epithelial $\mathrm{Cl}$ transport and suggested that menthol may have beneficial actions in treatment of cystic fibrosis (Morise et al., 2010). Similarly, menthol has been shown to interfere with tubulin depolymerization and promote apoptosis (Faridi et al., 2011). Overall, these studies indicate that menthol causes several effects on intracellular $\mathrm{Ca}^{2+}$ levels and other cellular events independent of TRP-channels.

\section{GABA and Glycine Receptors}

Receptors for inhibitory neurotransmitters $\gamma$-amino butyric acid (GABA) and glycine (Gly) belong to pentameric ligand-gated ion channel family. These receptors respond to GABA and Gly by opening a chloride-selective central pore. In the central nervous system, GABA is the major inhibitory neurotransmitter. It is synthesized in GABAergic neurons and in response to action potential, it is released from presynaptic buttons into the synaptic cleft. Subsequent to its release, GABA acts primarily at two different types of receptors: first the ionotropic $\mathrm{GABA}_{\mathrm{A}}$ receptors and secondly, the metabotropic, G-protein coupled $G_{A B A}$ receptors. In case of $G_{A B A}$ receptors, binding of GABA to its receptor causes a conformational change in its structure and leads to the opening of the channel. Activation of $\mathrm{GABA}_{\mathrm{A}}$ receptors causes hyperpolarization and eventually the suppression of neuronal activity (Fritschy et al., 2012; Sigel and Steinmann, 2012). On the other hand, the receptors for Gly are located primarily in the spinal cord and brain stem. Following its release from nerve endings, Gly binds to post-synaptic Gly receptor and opens a chloride channel intrinsic to the receptor (Yevenes and Zeilhofer, 2011; Dutertre et al., 2012).

In recent years, the actions of menthol and structurally related monoterpene analogs on $\mathrm{GABA}_{\mathrm{A}}$-receptors have attracted considerable attention. Notably, in majority of earlier investigations menthol was found to upregulate the function of $\mathrm{GABA}_{\mathrm{A}}$-receptors. In a previous investigation, actions of menthol and its structural analogs (monoterpenoid alcohols and ketones) were examined on recombinant human $\mathrm{GABA}_{\mathrm{A}}$ $(\alpha 1 \beta 2 \gamma 2 s)$ and glycine ( $\alpha 1$ homomers) receptors expressed in Xenopus oocytes (Hall et al., 2004). Monoterpences, in the concentration range of 10-300 $\mu \mathrm{M}$, caused a significant increase of GABA-induced currents in the following order: $(+)$-menthol $>(-)$-menthol $>$ borneol $>$ menthone $=$ camphor $=$ carvone . In this study menthol was found to be activated stereoselectively (Hall et al., 2004). Importantly, menthol up to concentration of $1 \mathrm{mM}$ did not induce any ion current indicating that this compound does not have direct agonist activity on $\mathrm{GABA}_{\mathrm{A}}$ receptor. Given its marked effects (e.g., at $100 \mu \mathrm{M}$, GABA and glycine $\mathrm{EC}_{20}$ responses increased by 496 and 135\%, respectively) potentiating effects of menthol was further investigated. Menthol, $100 \mu \mathrm{M}$, reduced $\mathrm{EC}_{50}$ values for Gly and GABA from 98 to $75 \mu \mathrm{M}$, and from 82 to $25 \mu \mathrm{M}$ respectively, without a significant effect on maximal responses (Hall et al., 2004).

In further studies on human $\alpha 1 \beta 2 \gamma 2 \mathrm{~s} \mathrm{GABA}_{\mathrm{A}}$ receptors expressed in Xenopus laevis oocytes (Watt et al., 2008), it was reported that when these compounds were co-applied with sub-maximal $\left(\mathrm{EC}_{20}\right)$ GABA concentrations, the amplitudes of current responses were increased in concentration-dependent manner in the following order: (+)-menthol $>$ isopulegol $>$ isomenthol $>\alpha$-terpineol $>>$ cyclohexanol. Importantly, flumazenil (a benzodiazepine antagonist) did not reverse menthol enhancement of GABA-induced currents while GABA responses activated by propofol $(50 \mu \mathrm{M})$ were significantly suppressed by menthol $(50 \mu \mathrm{M})$. $\mathrm{GABA}_{\mathrm{A}}$ receptors containing $\beta 2$ subunits with either a point mutation of a tyrosine to a tryptophan at the 444 position (TM-4) or a methionine residue to a tryptophan at the 286 position (in transmembrane domain 3, TM-3) are found to be insensitive to propofol modulation. Potentiation of GABA $\mathrm{EC}_{20}$ currents by menthol were equally eliminated in $\mathrm{GABA}_{\mathrm{A}} \alpha 1 \beta 2(\mathrm{M} 286 \mathrm{~W}) \gamma 2 \mathrm{~s}$ and $\alpha 1 \beta 2(\mathrm{Y} 444 \mathrm{~W}) \gamma 2 \mathrm{~s}$ receptors while potentiation by barbiturates, benzodiazepines, and steroids remained unaltered (Watt et al., 2008). The findings of this study showed that menthol acts on $\mathrm{GABA}_{\mathrm{A}}$ receptors via a site related to propofol modulation but distinct from action sites for barbiturates, benzodiazepines, and steroids. Finally, application of menthol, in an in vivo tadpole assay, resulted in a loss of righting reflex with an $\mathrm{EC}_{50}$ of $23 \mu \mathrm{M}(\sim 10$-fold less potent anesthesia than propofol). Thus, it is possible that menthol shares general anesthetic action with propofol (Watt et al., 2008) possibly by acting at similar binding sites on the $\mathrm{GABA}_{\mathrm{A}}$ receptor.

In radioligand binding studies, specific binding of $\left[{ }^{3} \mathrm{H}\right]$ flunitrazepam to $\mathrm{GABA}_{\mathrm{A}}$ receptors in primary cultures of mouse cortical neurons was not altered by up to $500 \mu \mathrm{M}$ concentrations of menthol (García et al., 2006). In another investigation, it was reported that only $(+)$-menthol, among the five menthol stereoisomers studied, was found to be active in potentiating the binding of $\left[{ }^{3} \mathrm{H}\right]$-flunitrazepam, an allosteric ligand for $\mathrm{GABA}_{\mathrm{A}}$ receptor (Corvalán et al., 2009) while (+) and (-)neomenthol were found to be inactive. In another radioligand binding study, monoterpenes such as carvacrol, citronellic acid, 1,8-Cineole, thymol, and pulegone significantly increased the specific binding of $\left[{ }^{3} \mathrm{H}\right]$-tbutylbicycloorthobenzoate (TBOB), a non-competitive inhibitor of picrotoxin. On the other hand, menthol and other monoterpenoids such as vanillin, camphor, and safrole, significantly suppressed the binding of $\left[{ }^{3} \mathrm{H}\right]-\mathrm{TBOB}$ in housefly head membrane preparations (Tong and Coats, 2012).

In another investigation, it was shown that the excitability of cultured rat hippocampal neurons were inhibited menthol (Zhang et al., 2008). In addition, menthol significantly inhibited the epileptic activity induced by pentylenetetrazole injection and electrical kindling in in vivo models (Zhang et al., 2008). It was reported that menthol not only increased the currents activated by low concentrations of GABA but also directly induced currents mediated by $\mathrm{GABA}_{\mathrm{A}}$ receptors in cultured hippocampal neurons. 
In addition, menthol significantly increased tonic GABAergic inhibition in the CA1 region of rat hippocampal slices. But phasic GABAergic inhibition remained unaffected. The structure-effect relationship of menthol suggested that hydroxyl group plays an important role in the enhancement of tonic $\mathrm{GABA}_{\mathrm{A}}$ receptors by menthol (Zhang et al., 2008). Another study examined the actions of menthol on respiratory rhythm generation in the brainstemspinal cord preparations from newborn rats (Tani et al., 2010). It was reported that menthol, by directly activating tonic GABA receptors, caused a significant inhibition of burst generation in pre-inspiratory neurons. In a recent study (Lau et al., 2014), the effects of menthol on $\mathrm{GABA}_{\mathrm{A}}$ receptors were examined in periaqueductal gray (PAG) neurons of midbrain slices It was found that menthol (150-750 $\mu \mathrm{M})$ induced prolongation of spontaneous $\mathrm{GABA}_{\mathrm{A}}$ receptor-mediated inhibitory post-synaptic currents in a concentration-dependent manner, but non-NMDA receptor-mediated excitatory post-synaptic currents remained unaltered. Effects of menthol were not changed by antagonists of TRPM8 and TRPA1 receptors, flumezanil, a benzodiazepine antagonist, and tetrodotoxin, sodium channel blocker. A tonic current, which was sensitive to the bicuculline and picrotoxin (both are $\mathrm{GABA}_{\mathrm{A}}$ receptor antagonists) was also enhanced by menthol. These results indicated that both synaptic and extrasynaptic populations of $\mathrm{GABA}_{\mathrm{A}}$ receptors are positively modulated by menthol in native PAG neurons.

The action of menthol on the Gly receptors are relatively less studied in comparison to $\mathrm{GABA}_{\mathrm{A}}$ receptors. In an earlier investigation (Hall et al., 2004), actions of menthol were studied on homomeric $\alpha 1$ glycine receptors expressed in Xenopus oocytes. It was reported that the function of Gly receptors was significantly enhanced by both $(+)$ and $(-)$ enantiomers of menthol and borneol.

\section{Serotonin Type-3 Receptors}

Serotonin type-3 $\left(5-\mathrm{HT}_{3}\right)$ receptors belong to Cys-loop family of ligand-gated ion channel family and therefore differ structurally and functionally from other G-protein coupled serotonin receptors. Human $5-\mathrm{HT}_{3}$ receptors are proposed to play important roles in neurodevelopment, nociception, psychiatric disorders such as depression, and motility of gastrointestinal system (Lummis, 2012; Engel et al., 2013). The actions of menthol on the functional properties of $5-\mathrm{HT}_{3}$ receptors were studied in recent investigations (Heimes et al., 2011; Ashoor et al., 2013b; Walstab et al., 2014; Ziemba et al., 2015). Actions of menthol on $5-\mathrm{HT}_{3}$ receptors were studied by Heimes et al. (2011) utilizing three different in vitro models: isotonic contractions of the isolated rat ileum and equilibrium competition binding studies using $\left[{ }^{3} \mathrm{H}\right] \mathrm{GR} 65630$, a $5-\mathrm{HT}_{3}$ receptor antagonist, and $\left[{ }^{14} \mathrm{C}\right]$ guanidinium influx into $\mathrm{N} 1 \mathrm{E}$ 115 cells which express $5-\mathrm{HT}_{3}$ receptors. Application of menthol suppressed $\left[{ }^{14} \mathrm{C}\right]$ guanidinium influx through $5-\mathrm{HT}_{3}$ receptors as well as 5-HT induced contractions of the ileum. However, specific binding of $\left[{ }^{3} \mathrm{H}\right] \mathrm{GR} 65630$ to $5-\mathrm{HT}_{3}$ receptor was not altered by menthol. In this investigation, it was suggested that antiemetic actions of menthol occur at least partly by acting as a negative allosteric modulator of the $5-\mathrm{HT}_{3}$ receptors; in other words, by binding to an allosteric modulatory site which is distinct from the binding site of serotonin. In another recent investigation, Ashoor et al. (2013b) studied the actions of menthol on the functional properties of human $5-\mathrm{HT}_{3 \mathrm{~A}}$ receptors expressed in $X$. laevis oocytes. Menthol reversibly suppressed 5-HT-activated inward currents in a concentration-dependent manner with an IC $_{50}$ value of $163 \mu \mathrm{M}$. The time course of the inhibitory effect of menthol was slow and reached a steady-state level within 10-15 min. However, the effect did not involve G-proteins, since GTP $\gamma S$ activity remained unchanged. In addition, pretreatment with pertussis toxin, which inhibits $G_{i}$ and $G_{0}$ proteins, did not alter the extent of menthol inhibition. Racemic, $(-),(+)$ menthols inhibited $5-\mathrm{HT}_{3}$ currents to the same extent suggesting that the effects of menthol on $5-\mathrm{HT}_{3}$ receptors are not stereoselective. Increasing concentrations of 5-HT did not reverse the inhibition induced by menthol. Moreover, menthol did not affect specific binding of the $\left[{ }^{3} \mathrm{H}\right] \mathrm{GR} 65630$, indicating that this compound acts as a non-competitive antagonist of the $5-\mathrm{HT}_{3}$ receptor. Finally, in acutely dissociated nodose ganglion neurons, $5-\mathrm{HT}_{3}$ receptormediated currents were inhibited by menthol. The results of this study indicated that in both heterologous expression systems and in neurons, menthol acts as a negative allosteric modulator of $5-\mathrm{HT}_{3}$ receptors. In another recent study actions of menthol was investigated in HEK293 cells expressing human recombinant homomeric $5-\mathrm{HT}_{3 \mathrm{~A}}$ - and heteromeric $5-\mathrm{HT}_{3 \mathrm{AB}}$ receptors using a luminescence-based $\mathrm{Ca}^{2+}$ assay, membrane potential assay, and radioligand binding assay (Walstab et al., 2014). The results of this study indicated that $(-)$ isomer of menthol inhibited $5-\mathrm{HT}_{3}$ receptors with an $\mathrm{IC}_{50}$ of $20 \mu \mathrm{M}$ in a non-competitive manner. Importantly, the potency of $(+)$-menthol was significantly less than that of the $(-)$ stereoisomer. In addition, (+)-menthol, compared to $(-)$ menthol, was significantly less potent on $5-\mathrm{HT}_{3 \mathrm{~A}}$ vs $5-\mathrm{HT}_{3 \mathrm{AB}}$ receptors. Overall, (-)-menthol was $11-$ fold more potent toward the homomeric $5-\mathrm{HT}_{3 \mathrm{~A}}$ receptor. Above-mentioned studies demonstrate that menthol is a negative allosteric modulator of $5-\mathrm{HT}_{3}$ receptors. Similar to menthol, thujone, another monoterpene chemically related to menthol, has also been demonstrated to suppress the function of $5-\mathrm{HT}_{3}$ receptors (Deiml et al., 2004).

\section{Nicotinic Acetylcholine Receptors}

The nicotinic acetylcholine receptors (nAChRs) are cationpermeable ion channel-receptor complex activated by the neurotransmitter acetylcholine. The nAChRs is a member of Cys-loop receptor family, which also includes the $\mathrm{GABA}_{\mathrm{A}}$, GABA $C$, Gly, and serotonin $5-\mathrm{HT}_{3}$, receptors. The nAChRs also play important roles in several physiological functions and pathological conditions, including the modulation of neurotransmitter release, the secretion of hormones, and regulation of neuronal excitability (Dani and Bertrand, 2007; Dineley et al., 2015). The nAChRs are expressed throughout the neurons of central and peripheral nervous systems, as well as cells of the other peripheral tissues (Dani and Bertrand, 2007; Albuquerque et al., 2009). Currently, nine different nAChR subunits have shown to be expressed ( $\alpha 2-7$ and $\beta 2-4)$ in the mammalian brain. The subunits combinations, as either homomeric or heteromeric complexes, can occur resulting in functionally diverse pentameric receptors (Albuquerque et al., 
2009; Dineley et al., 2015). The main receptor subtypes expressed in the brain are $\alpha 7$ containing subunits and those composed of both $\alpha$ and $\beta$ subunits, including the $\alpha 4 \beta 2^{*}$ and $\alpha 3 \beta 4^{*}$ subtypes; the ${ }^{*}$ designates that these receptors can contain other $\alpha$ and $\beta$ subunits as well. In searching for new selective molecules that modulate the functional properties of $\mathrm{nACh}$ receptors, naturally produced chemicals have shown to be a good source at least for generations of structural models (Daly, 2005; Romanelli et al., 2007).

In tobacco industry, menthol is commonly employed to mask the unpleasant tobacco test, increase the ease of smoking and offer a cooling sensation that appeal to many smokers (Ahijevych and Garrett, 2004). Moreover, it has been reported that menthol is present in 90 percent of tobacco products in varying concentrations (Foulds et al., 2010). Menthol, as an additive to tobacco products, has come under scrutiny following several FDA reports (Benowitz and Samet, 2011), indicating that menthol can enhance smoking behavior and stimulate adverse effect of smoking on health (Kabbani, 2013; Wickham, 2015). The results of epidemiological studies suggest that smoking of mentholated cigarettes is more widespread in ethnic and racial minority populations (Ahijevych and Garrett, 2010; Foulds et al., 2010). It is also important to note that an association between a difficulty in quitting smoking and smoking mentholated cigarettes is also greater in ethnic and racial minority populations as well as young smokers (Foulds et al., 2010). Therefore, it is essential to investigate the cellular and molecular mechanisms of interaction between $\mathrm{nAChRs}$ and menthol.

Functional interaction between nicotinic receptors and menthol has been reported earlier both in vitro and in vivo investigations (Dessirier et al., 2001; Ruskin et al., 2008; Willis et al., 2011; Hans et al., 2012; Ashoor et al., 2013a; Amato et al., 2014b). In an earlier study, it was found that menthol significantly reduces sensory perception and irritation caused by nicotine (Dessirier et al., 2001) and by inhalation of cigarette smoke (Willis et al., 2011). In addition to these findings, nicotine-induced decreases in body temperature, as a result of cutaneous vasodilation, are reduced considerably following the administration of both acute and chronic menthol (Ruskin et al., 2008). In a recent investigation, the extent of gastric relaxation induced by menthol was considerably decreased in the presence of hexamethonium, a nAChR blocker (Amato et al., 2014b). Menthol, at concentrations that did not alter gastric tone, decreased the contraction caused by nAChR agonist, dimethylphenylpiperazinium. The co-application of hexamethonium and phentholamine, $\alpha$-adrenergic receptor antagonist or hexamethonium and atropine, muscarinic receptor antagonist, did not cause any additive decrease of the mentholinduced relaxation. In this study, authors concluded that the interaction between $\mathrm{nAChR}$ and menthol is likely to be an important stage for menthol-induced relaxation of gastric muscle (Amato et al., 2014b).

Electrophysiological studies investigating the effects of menthol on different $\mathrm{nAChR}$ subtypes have also been conducted (Hans et al., 2012; Ashoor et al., 2013a). It was reported that, in trigeminal neurons, nicotine-induced whole-cell currents through nACh receptors was reversibly inhibited with an $\mathrm{IC}_{50}$ of $111 \mu \mathrm{M}$. Single channel experiments on human $\alpha 4 \beta 2 \mathrm{nAChR}$ expressed in HEKtsA210 cells indicated that menthol induced a decrease of channel open time, increase in single channel amplitude, and increase of channel closed time leading to overall reduction in single channel currents. Moreover, menthol did not alter the potency (nicotine's $\mathrm{EC}_{50}$ value) on recombinant human $\alpha 4 \beta 2$ nAChRs but induced a substantial decrease in the efficacy of nicotine. All together, these results demonstrated that menthol is a negative allosteric modulator of $\alpha 4 \beta 2 \mathrm{nAChRs}$ (Hans et al., 2012). Clinical studies employing positron emission tomography scanning with the $\alpha 4 \beta 2$ radioligand indicated that, in line with the results of in vitro studies, menthol smokers have 9-28\% higher $\alpha 4 \beta 2 \mathrm{nAChR}$ densities than non-menthol smokers across regions (Brody et al., 2013).

In a recent study, the effect of long-term menthol application was investigated on midbrain neurons containing nAChRs (Henderson et al., 2016). Menthol alone increased the number of $\alpha 4$ and $\alpha 6 \mathrm{nAChR}$ subunits in midbrain dopaminergic neurons from mice expressing fluorescent nAChR subunits. However, this upregulation did not occur in midbrain GABAergic neurons suggesting that chronic menthol application produced a cell-type-selective upregulation of $\alpha 4^{*}$ nAChRs. These findings complemented that of chronic nicotine alone, which upregulates $\alpha 4$ subunit-containing $\left(\alpha 4^{*}\right)$ nAChRs in GABAergic but not dopaminergic neurons. Further studies in cultured midbrain neurons and mouse brain slices indicated that menthol decreased dopaminergic neuron firing frequency and altered dopaminergic neuron excitability following $\mathrm{nAChR}$ activation. Furthermore, exposure to menthol before nicotine stopped nicotine reward-related behavior in mice. In neuroblastoma cells transfected with fluorescent nAChR subunits, exposure to menthol (500 nM) alone also increased the number of nAChRs and favored the formation of $(\alpha 4) 3(\beta 2) 2$ nAChRs. This effect contrasted with the action of nicotine, which favors $(\alpha 4) 2(\beta 2) 3$ nAChRs (Henderson et al., 2016). Menthol alone also increases the number of $\alpha 6 \beta 2$ receptors that exclude the $\beta 3$ subunit. Thus, it appears that lower-sensitivity $\alpha 4^{*}$ and $\alpha 6$ subunit-containing $\mathrm{nAChRs}$ were stabilized by menthol. The suppression of nicotine reward-related behavior may be mediated through menthol's ability to stabilize lower-sensitivity nAChRs and alter dopaminergic neuron excitability. Overall these studies indicated that menthol increases the number of nAChRs in the mouse brain at a dose that matches nicotine in its ability to increase nAChR number. Menthol also changes the function of midbrain dopamine neurons, and prevents behaviors related to nicotine reward. These findings suggest that menthol is more than an "inert" additive to tobacco and it is able to alter the functional properties of midbrain dopamine neurons in the mesolimbic reward pathway. In fact, another recent study indicate that menthol enhances nicotine-induced changes in nAChRs expressed on midbrain dopaminergic neurons (Henderson et al., 2017). Menthol plus nicotine upregulates $\mathrm{nAChR}$ number and function on midbrain dopaminergic neurons more than nicotine alone. Menthol also enhances nicotine-induced changes in dopaminergic neuron excitability. Furthermore, in a conditioned place preference assay, menthol plus nicotine produces greater 
reward-related behavior than nicotine alone (Henderson et al., 2017).

In addition to $\alpha 4 \beta 2$ containing receptors, function of $\alpha 7$ nAChRs was also reported to be altered by menthol. Utilizing a two-electrode voltage-clamp technique, it was demonstrated that menthol reversibly inhibited human $\alpha 7-n A C h$ receptors expressed in Xenopus oocytes (Ashoor et al., 2013a). Inhibitory effect of menthol did not involve the activation of endogenously expressed $\mathrm{Ca}^{2+}$-dependent $\mathrm{Cl}^{-}$channels in oocytes and the effect was not dependent on changes in the membrane potential. Moreover, increasing the concentrations of ACh did not alter the inhibition by menthol. In addition, the specific binding of $\alpha$ bungarotoxin was not changed by menthol. Furthermore, studies of $\alpha 7-n A C h$ receptors endogenously expressed in neuronal cells indicated that menthol suppresses $\mathrm{Ca}^{2+}$ transients mediated by the activation of $\alpha 7$-nACh receptors in the cell body and neurite. Over all, these findings indicate that menthol non-competitively inhibits the function of $\alpha$ 7-nACh receptors (Ashoor et al., 2013a).

In addition to centrally located $\alpha 7$ and $\alpha 4 \beta 2 \mathrm{nAChRs,} \mathrm{the}$ effects of menthol have also been reported on $\alpha 3 \beta 4$, the major nicotinic subtype expressed in sensory nerves (Ton et al., 2015). In this study, menthol markedly suppressed the activity of nAChR as assessed by ${ }^{86} \mathrm{Rb}^{+}$efflux, $\mathrm{Ca}^{2+}$ imaging, and voltage-clamp experiments. Menthol inhibited the function of nAChRs in a voltage-independent manner. In addition, menthol decreased the mean open time of single channels without altering their conductance, disagreeing with a simple channelblocking action. Furthermore, the recovery of nAChRs from desensitization menthol was significantly slowed or prevented by menthol, suggesting that menthol probably stabilizes a desensitized state of nAChRs. It was also demonstrated that menthol at concentrations up to $1 \mathrm{mM}$ did not interact with the orthosteric nAChR binding site labeled by $\left[{ }^{3} \mathrm{H}\right]$ epibatidine, indicating that menthol causes desensitization of $\alpha 3 \beta 4 \mathrm{nAChRs}$ by an allosteric mechanism (Ton et al., 2015).

In conclusion, in both neural and non-neural nACh receptors, menthol presented a significant activity on the function of nACh receptor that requires further investigations. Drug development efforts have recently focused on direct manipulation of $\alpha 7$ and $\alpha 4 \beta 2 \mathrm{nACh}$ receptors. Menthol and related monoterpenes could be helpful in developing compounds that influence different nAChR subtypes or provide high selectivity for these subtypes.

\section{RELEVANT MENTHOL CONCENTRATIONS}

In the literature, there are some pharmacokinetic studies available for menthol. In an earlier study, the no-observed-adverse-effectlevel after oral intake was found to be $667 \mathrm{mg} / \mathrm{kg} /$ day (National Toxicology Program, 1979). The lethal menthol concentration in orally fed mice was reported to be in the range of 2,900-6,000 $\mathrm{mg} / \mathrm{kg}$ body weight, indicating that menthol, at the doses used in most in vitro studies (10 $\mu \mathrm{M}$ to $10 \mathrm{mM})$ is well-tolerated. In another study, the plasma menthol concentration rose to $20 \mu \mathrm{M}$ within $1 \mathrm{~h}$ in rats that have been administered $400 \mathrm{mg}$ of menthol/kg body weight I.P. (Spichiger et al., 2004). In an earlier study in rodents, it was reported that the average nasal tissue concentration of inhaled menthol applications (at 0.65 $\mu \mathrm{M}$ in vapor or $16 \mathrm{ppm}$ ) was about $150 \mu \mathrm{M}$ (Willis et al., 2011). In clinical studies, topical menthol application (30\%; 1.9 M) has been employed consistently, without initiating any skin irritation or other side effects (Hatem et al., 2006). These results indicate that the effects of menthol used in the concentration range of $10 \mu \mathrm{M}$ to $10 \mathrm{mM}$ in most in vitro studies are likely to be pharmacologically relevant. In addition, the concentrations of menthol utilized in in vitro studies are below or within the range of FDA regulated concentrations utilized in creams $(2 \% \mathrm{v} / \mathrm{v} ; 128$ $\mathrm{mM})$ and over-the-counter pain rubs $(4 \% \mathrm{v} / \mathrm{v} ; 256 \mathrm{mM})(\mathrm{OECD}$, 2003).

\section{MECHANISMS OF MENTHOL ACTIONS}

Menthol, as mentioned earlier, is a highly hydrophobic compound with Log p value of 3.4 (Turina et al., 2006; Zunino et al., 2011). In line with these findings, menthol and other structurally related monoterpenes partition into biological membranes and cause significant alterations in numerous physico-chemical characteristics of lipid bilayers (Sánchez et al., 2004; Turina et al., 2006; Zunino et al., 2011). A central question has been if the effects of these hydrophobic compounds are mediated by their direct interaction with integral membrane proteins (for example ion channels and transporters) and/or by altering the physico-chemical characteristics of the lipid membranes and indirectly affecting channel function (Lee, 2011). This dichotomy demonstrates a main challenge in understanding the mechanisms of not only menthol actions but also other hydrophobic compounds such as general anesthetics (Howard et al., 2014) alcohols (for a review Howard et al., 2014; Trudell et al., 2014), terpenes ( $\mathrm{Oz}$ et al., 2015), steroids (Hill et al., 2015), and endocannabinoids $(\mathrm{Oz}, 2006)$. It appears that these hydrophobic molecules bind to sites that are distinct from the sites for binding probes (radioligands or toxins) and cause significant alterations on functions of these channels (Anishkin et al., 2014; Poveda et al., 2014). It is likely that the lipophilic molecules such as menthol partition into lipid bilayer membranes and alter the gating properties of both voltage- and ligandgated ion channels. In most in vitro studies, menthol and other hydrophobic monoterpenes have been shown to act on ion channels at a concentration range of $10 \mu \mathrm{M}$ to $10 \mathrm{mM}$. In fact, this is not a unique pharmacological property of monoterpenes. Several other hydrophobic molecules, such as alcohols and general anesthetics also act at similarly high concentrations (high $\mu \mathrm{M}$ to low $\mathrm{mM}$ ).

In earlier studies, it has been shown that all voltagegated ion channels (VGICs) comprises a common domain of six helical transmembrane segments (S1-S6). Among these segments, $S 4$ has been shown to have a symmetrical arrangement of charged amino acids, with each third amino acid being lysine or arginine. Hence, S4 has been thought as the key contender for the voltage-sensing segment of VGICs. Previous crystallographic examinations of KcsA $\mathrm{K}^{+}$channels have shown that the gating domain of the channel is located at the 
lipid-protein interface (Valiyaveetil et al., 2002; Ruta and MacKinnon, 2004). It is possible that gating domains of other VGICs also have similar orientations (Lee et al., 2005; Moreau et al., 2014; Poveda et al., 2014). In this situation, hydrophobic allosteric modulators such as menthol and other monoterpenes can operate as gating modifiers by altering the energy constraints for the movement of lipid-embedded gating domains of VGICs. As a result, changes in energy requirements of gating related conformational alterations of membrane proteins can be due to menthol-induced modifications in physicochemical characteristics of membranes. In a number of previous investigations, physiochemical characteristics of lipid bilayer membranes such as membrane fluidity and membrane thickness have been shown to be modified by menthol and other related monoterpenes (Sánchez et al., 2004; Turina et al., 2006; Reiner et al., 2009; Zunino et al., 2011).

It is known that, similar to VGIC, the energetic requirements for gating-related conformational alterations of ligand-gated ion channels (LGICs) also can be changed by actions of menthol on lipid membranes. In previous investigations, it was demonstrated that even slight changes in adjacent lipid structure can cause important alterations in the function of LGICs by changing the energetics of conformational transitions in the protein structure (Fantini and Barrantes, 2009; Barrantes et al., 2010). Besides their interaction with membranes, menthol and other monoterpenes can bind directly to residues of the transmembrane domains and alter the functional properties of LGICs. For instance, a recent investigation has identified transmembrane residues that eliminate the agonist action of

\section{REFERENCES}

Ahijevych, K., and Garrett, B. E. (2004). Menthol pharmacology and its potential impact on cigarette smoking behavior. Nicotine Tob. Res. 1, 17-28. doi: 10.1080/14622200310001649469

Ahijevych, K., and Garrett, B. E. (2010). The role of menthol in cigarettes as a reinforce of smoking behavior. Nicotine Tob. Res. 2, 110-116. doi: $10.1093 / \mathrm{ntr} / \mathrm{ntq} 203$

Albin, K. C., Carstens, M. I., and Carstens, E. (2008). Modulation of oral heat and cold pain by irritant chemicals. Chem. Senses 33, 3-15. doi: 10.1093/chemse/bjm056

Albuquerque, E. X., Pereira, E. F., Alkondon, M., and Rogers, S. W. (2009). Mammalian nicotinic acetylcholine receptors: from structure to function. Physiol. Rev. 89, 73-120. doi: 10.1152/physrev.00015.2008

Amato, A., Liotta, R., and Mulè, F. (2014a). Effects of menthol on circular smooth muscle of human colon: analysis of the mechanism of action. Eur. J. Pharmacol. 740, 295-301. doi: 10.1016/j.ejphar.2014.07.018

Amato, A., Serio, R., and Mulè, F. (2014b). Involvement of cholinergic nicotinic receptors in the menthol-induced gastric relaxation. Eur. J. Pharmacol. 745, 129-134. doi: 10.1016/j.ejphar.2014.10.012

Anishkin, A., Loukin, S. H., Teng, J., and Kung, C. (2014). Feeling the hidden mechanical forces in lipid bilayer is an original sense. Proc. Natl. Acad. Sci. U.S.A. 111, 7898-7905. doi: 10.1073/pnas.1313364111

Ashoor, A., Nordman, J. C., Veltri, D., Yang, K. H., Al Kury, L., Shuba, Y., et al. (2013a). Menthol binding and inhibition of $\alpha 7$-nicotinic acetylcholine receptors. PLoS ONE 8:e67674. doi: 10.1371/journal.pone.0067674

Ashoor, A., Nordman, J. C., Veltri, D., Yang, K. H., Shuba, Y., Al Kury, L., et al. (2013b). Menthol inhibits 5-HT3 receptor-mediated currents. J. Pharmacol. Exp. Ther. 347, 398-409. doi: 10.1124/jpet.113.203976 thymol and carvacrol on human $5-\mathrm{HT}_{3}$ receptors, or confer this property on mouse $5-\mathrm{HT}_{3}$ receptors that are previously insensitive to these compounds (Lansdell et al., 2015). Moreover, at least in some investigations, stereoselectivity for the effects of monoterpenes was demonstrated (Hall et al., 2004; Watt et al., 2008; Corvalán et al., 2009; Gonçalves et al., 2010; Heimes et al., 2011; Kawasaki et al., 2013; Walstab et al., 2014). Furthermore, specific amino acid residues mediating the actions of monoterpenes were identified on $5-\mathrm{HT}_{3}$ (Lansdell et al., 2015) and $\mathrm{GABA}_{\mathrm{A}}$ receptors (Watt et al., 2008). Thus, it is possible that both direct binding of hydrophobic compounds to ion channel residues and changing the physicochemical properties of biological membranes can contribute to overall actions of menthol and other monoterpenes on the functional properties of ion channels.

\section{AUTHOR CONTRIBUTIONS}

MO and LA: Idea, design, writing, and submission. EE, KY, and FH: Substantial contribution to the conception, formulation, and critical revision of the manuscript. All authors gave approval for the final submission of the review and agreed be accountable for all aspects of the work.

\section{ACKNOWLEDGMENTS}

This study was in part supported by the research funds from United Arab Emirates University and Qatar Foundation.

Badou, A., Jha, M. K., Matza, D., and Flavell, R. A. (2013). Emerging roles of L-type voltage-gated and other calcium channels in T lymphocytes. Front. Immunol. 4:243. doi: 10.3389/fimmu.2013.00243

Bandell, M., Dubin, A. E., Petrus, M. J., Orth, A., Mathur, J., Hwang, S. W., et al. (2006). High-throughput random mutagenesis screen reveals TRPM8 residues specifically required for activation by menthol. Nat. Neurosci. 9, 493-500. doi: $10.1038 / \mathrm{nn} 1665$

Bandell, M., Story, G. M., Hwang, S. W., Viswanath, V., Eid, S. R., Petrus, M. J., et al. (2004). Noxious cold ion channel TRPAl is activated by pungent compounds and bradykinin. Neuron 41, 849-857. doi: 10.1016/S0896-6273(04)00150-3

Bannister, R. A., and Beam, K. G. (2013). Ca(V)1.1: the atypical prototypical voltage-gated $\mathrm{Ca}^{2}$ ? channel. Biochim. Biophys. Acta 1828, 1587-1597. doi: 10.1016/j.bbamem.2012.09.007

Barrantes, F. J., Bermudez, V., Borroni, M. V., Antollini, S. S., Pediconi, M. F., Baier, J. C., et al. (2010). Boundary lipids in the nicotinic acetylcholine receptor microenvironment. J. Mol. Neurosci. 40, 87-90. doi: 10.1007/s12031-009-9262-z

Baylie, R. L., Cheng, H., Langton, P. D., and James, A. F. (2010). Inhibition of the cardiac L-type calcium channel current by the TRPM8 agonist, (-)-menthol. J. Physiol. Pharmacol. 61, 543-550. doi: 10.1124/jpet.107.132456

Behrendt, H. J., Germann, T., Gillen, C., Hatt, H., and Jostock, R. (2004). Characterization of the mouse cold-menthol receptor TRPM8 and vanilloid receptor type-1 VR1 using a fluorometric imaging plate reader (FLIPR) assay. Br. J. Pharmacol. 141, 737-745. doi: 10.1038/sj.bjp.0705652

Benowitz, N. L., and Samet, J. M. (2011). The threat of menthol cigarettes to U.S. public health. N. Engl. J. Med. 364, 2179-2181. doi: 10.1056/NEJMp1103610

Billeter, A. T., Hellmann, J. L., Bhatnagar, A., and Polk, H. C. Jr. (2014). Transient receptor potential ion channels: powerful regulators of cell function. Ann. Surg. 259, 229-235. doi: 10.1097/SLA.0b013e3182a6359c 
Bradshaw, H. B., Raboune, S., and Hollis, J. L. (2013). Opportunistic activation of TRP receptors by endogenous lipids: exploiting lipidomics to understand TRP receptor cellular communication. Life Sci. 92, 404-409. doi: $10.1016 /$ j.lfs.2012.11.008

Brody, A. L., Mukhin, A. G., La Charite, J., Ta, K., Farahi, J., Sugar, C. A., et al. (2013). Up-regulation of nicotinic acetylcholine receptors in menthol cigarette smokers. Int. J. Neuropsychopharmacol. 16, 957-966. doi: $10.1017 /$ S1461145712001022

Cannon, S. C., Aminoff, M. J., and Daroff, R. B. (2014). "Ion channels, overview," in Encyclopedia of the Neurological Sciences, 2nd Edn, eds B. Robert, M. D. Daroff, and M. J. Aminoff (Oxford: Academic Press), 747-751.

Catterall, W. A., Lennarz, W. J., and Lane, M. D. (2013). "Voltage-gated sodium channels: structure, function, and pathophysiology," in Encyclopedia of Biological Chemistry, eds W. J. Lennarz and M. D. Lane (Waltham, MA: Academic Press), 564-569.

Cheang, W. S., Lam, M. Y., Wong, W. T., Tian, X. Y., Lau, C. W., Zhu, Z., et al. (2013). Menthol relaxes rat aortae, mesenteric and coronary arteries by inhibiting calcium influx. Eur. J. Pharmacol. 702, 79-84. doi: 10.1016/j.ejphar.2013.01.028

Clapham, D. E., and Squire, L. R. (2009). "Transient receptor potential (TRP) channels," in Encyclopedia of Neuroscience, ed L. R. Squire (Oxford: Academic Press), 1109-1133.

Corvalán, N. A., Zygadlo, J. A., and García, D. A. (2009). Stereo-selective activity of menthol on GABA(A) receptor. Chirality 21, 525-530. doi: 10.1002/chir.20631

Daly, J. W. (2005). Nicotinic agonists, antagonists, and modulators from natural sources. Cell Mol. Neurobiol. 25, 513-552. doi: 10.1007/s10571-005-3968-4

Dani, J. A., and Bertrand, D. (2007). Nicotinic acetylcholine receptors and nicotinic cholinergic mechanisms of the central nervous system. Annu. Rev. Pharmacol. Toxicol. 47, 699-729. doi: 10.1146/annurev.pharmtox.47.120505. 105214

Deiml, T., Haseneder, R., Zieglgansberger, W., Rammes, G., Eisensamer, B., Rupprecht, R., et al. (2004). a-Thujone reduces 5-HT3 receptor activity by an effect on the agonist-induced desensitization. Neuropharmacology 46, 192-201. doi: 10.1016/j.neuropharm.2003.09.022

Dessirier, J. M., O’Mahony, M., and Carstens, E. (2001). Oral irritant properties of menthol: sensitizing and desensitizing effects of repeated application and cross-desensitization to nicotine. Physiol. Behav. 73, 25-36. doi: 10.1016/S0031-9384(01)00431-0

Dierkes, P. W., Hochstrate, P., and Schlue, W. R. (1997). Voltage-dependent $\mathrm{Ca}^{2+}$ influx into identified leech neurones. Brain Res. 746, 285-293. doi: 10.1016/S0006-8993(96)01264-4

Dineley, K. T., Pandya, A. A., and Yakel, J. L. (2015). Nicotinic ACh receptors as therapeutic targets in CNS disorders. Trends Pharmacol. Sci. 36, 96-108. doi: 10.1016/j.tips.2014.12.002

Dutertre, S., Becker, C. M., and Betz, H. (2012). Inhibitory glycine receptors: an update. J. Biol. Chem. 287, 40216-40223. doi: 10.1074/jbc.R112.408229

Eccles, R. (1994). Menthol and related cooling compounds. J. Pharm. Pharmacol. 46, 618-630. doi: 10.1111/j.2042-7158.1994.tb03871.x

Engel, M., Smidt, M. P., and van Hooft, J. A. (2013). The serotonin 5-HT3 receptor: a novel neurodevelopmental target. Front. Cell Neurosci. 7:76. doi: $10.3389 /$ fncel.2013.00076

Fantini, J., and Barrantes, F. J. (2009). Sphingolipid/cholesterol regulation of neurotransmitter receptor conformation and function. Biochim. Biophys. Acta 1788, 2345-2361. doi: 10.1016/j.bbamem.2009.08.016

Faridi, U., Sisodia, B. S., Shukla, A. K., Shukla, R. K., Darokar, M. P., Dwivedi, U. N., et al. (2011). Proteomics indicates modulation of tubulin polymerization by L-menthol inhibiting human epithelial colorectal adenocarcinoma cell proliferation. Proteomics 11, 2115-2119. doi: 10.1002/pmic.2010 00691

Filippov, I. B., Vladymyrova, I. A., Kuliieva, I. M., Skryma, R., Prevarskaia, N., and Shuba, I. M. (2009). Modulation of the smooth muscle contractions of the rat vas deferens by TRPM8 channel agonist menthol. Fiziol. Zh. 55, 30-40.

Foulds, J., Hooper, M. W., Pletcher, M. J., and Okuyemi, K. S. (2010). Do smokers of menthol cigarettes find it harder to quit smoking? Nicotine Tob. Res. 2, 102-109. doi: $10.1093 / \mathrm{ntr} / \mathrm{ntq} 166$

Freichel, M., and Flockerzi, V. (2007). Biological functions of TRPs unravelled by spontaneous mutations and transgenic animals. Biochem. Soc. Trans. 35, 120-123. doi: 10.1042/BST0350120
Fritschy, J. M., Panzanelli, P., and Tyagarajan, S. K. (2012). Molecular and functional heterogeneity of GABAergic synapses. Cell Mol. Life Sci. 69, 2485-2499. doi: 10.1007/s00018-012-0926-4

Galeotti, N., Di Cesare, M. L., Mazzanti, G., Bartolini, A., and Ghelardini, C. (2002). Menthol: a natural analgesic compound. Neurosci. Lett. 322, 145-148. doi: 10.1016/S0304-3940(01)02527-7

Galeotti, N., Ghelardini, C., Mannelli, L., Mazzanti, G., Baghiroli, L., and Bartolini, A. (2001). Local anaesthetic activity of (+)- and (-)-menthol. Planta Med. 67, 174-176. doi: 10.1055/s-2001-11515

García, D. A., Bujons, J., Vale, C., and Suñol, C. (2006). Allosteric positive interaction of thymol with the GABAA receptor in primary cultures of mouse cortical neurons. Neuropharmacology 50, 25-35. doi: 10.1016/j.neuropharm.2005.07.009

Gaudioso, C., Hao, J., Martin-Eauclaire, M. F., Gabriac, M., and Delmas, P. (2012). Menthol pain relief through cumulative inactivation of voltagegated sodium channels. Pain 153, 473-484. doi: 10.1016/j.pain.2011. 11.014

Gees, M., Owsianik, G., Nilius, B., and Voets, T. (2012). TRP channels. Compr. Physiol. 2, 563-608. doi: 10.1002/cphy.c110026

Gonçalves, J. C., Alves Ade, M., de Araújo, A. E., Cruz, J. S., and Araújo, D. A. (2010). Distinct effects of carvone analogues on the isolated nerve of rats. Eur. J. Pharmacol. 645, 108-112. doi: 10.1016/j.ejphar.2010. 07.027

González, C., Baez-Nieto, D., Valencia, I., Oyarzún, I., Rojas, P., Naranjo, D., et al. (2012). K(+) channels: function-structural overview. Compr. Physiol. 2 2087-2149. doi: 10.1002/cphy.c110047

Green, B. G. (1986). Menthol inhibits the perception of warmth. Physiol. Behav. 38, 833-838. doi: 10.1016/0031-9384(86)90050-8

Haeseler, G., Maue, D., Grosskreutz, J., Bufler, J., Nentwig, B., Piepenbrock, S., et al. (2002). Voltage-dependent block of neuronal and skeletal muscle sodium channels by thymol and menthol. Eur. J. Anaesthesiol. 19, 571-579. doi: 10.1097/00003643-200208000-00005

Hall, A. C., Turcotte, C. M., Betts, B. A., Yeung, W. Y., Agyeman, A. S., and Burk, L. A. (2004). Modulation of human GABAA and glycine receptor currents by menthol and related monoterpenoids. Eur. J. Pharmacol. 506, 9-16. doi: 10.1016/j.ejphar.2004.10.026

Hans, M., Wilhelm, M., and Swandulla, D. (2012). Menthol suppresses nicotinic acetylcholine receptor functioning in sensory neurons via allosteric modulation. Chem. Senses 37, 463-469. doi: 10.1093/chemse/ bjr128

Hatem, S., Attal, N., Willer, J. C., and Bouhassira, D. (2006). Psychophysical study of the effects of topical application of menthol in healthy volunteers. Pain 122, 190-196. doi: 10.1016/j.pain.2006.01.026

Hawthorn, M., Ferrante, J., Luchowski, E., Rutledge, A., Wei, X. Y., and Triggle, D. J. (1988). The actions of peppermint oil and menthol on calcium channel dependent processes in intestinal, neuronal and cardiac preparations. Aliment. Pharmacol. Ther. 2, 101-118. doi: 10.1111/j.1365-2036.1988.tb00677.x

Heimes, K., Hauk, F., and Verspohl, E. J. (2011). Mode of action of peppermint oil and (-)-menthol with respect to 5-HT3 receptor subtypes: binding studies, cation uptake by receptor channels and contraction of isolated rat ileum. Phytother. Res. 25, 702-708. doi: 10.1002/ptr.3316

Henderson, B. J., Wall, T. R., Henley, B. M., Kim, C. H., McKinney, S., and Lester, H. A. (2017). Menthol enhances nicotine reward-related behavior by potentiating nicotine-induced changes in nAChR function, nAChR upregulation, and DA neuron excitability. Neuropsychopharmacology doi: 10.1038/npp.2017.72. [Epub ahead of print].

Henderson, B. J., Wall, T. R., Henley, B. M., Kim, C. H., Nichols, W. A., Moaddel, R., et al. (2016). Menthol alone upregulates midbrain nAChRs, alters nAChR subtype stoichiometry, alters dopamine neuron firing frequency, and prevents nicotine reward. J. Neurosci. 36, 2957-2974. doi: 10.1523/JNEUROSCI.4194-15.2016

Hill, M., Dušková, M., and Stárka, L. (2015). Dehydroepiandrosterone, its metabolites and ion channels. J. Steroid Biochem. Mol. Biol. 145, 293-314. doi: 10.1016/j.jsbmb.2014.05.006

Hills, J. M., and Aaronson, P. I. (1991). The mechanism of action of peppermint oil on gastrointestinal smooth muscle. An analysis using patch clamp electrophysiology and isolated tissue pharmacology in rabbit and guinea pig. Gastroenterology 101, 55-65. doi: 10.1016/0016-5085(91)90459-X 
Hofmann, F., Flockerzi, V., Kahl, S., and Wegener, J. W. (2014). L-type CaV1.2 calcium channels: from in vitro findings to in vivo function. Physiol. Rev. 94, 303-326. doi: 10.1152/physrev.00016.2013

Howard, R. J., Trudell, J. R., and Harris, R. A. (2014). Seeking structural specificity: direct modulation of pentameric ligand-gated ion channels by alcohols and general anesthetics. Pharmacol. Rev. 66, 396-412. doi: 10.1124/pr.113.007468

Ito, S., Kume, H., Shiraki, A., Kondo, M., Makino, Y., Kamiya, K., et al. (2008). Inhibition by the cold receptor agonists menthol and icilin of airway smooth muscle contraction. Pulm. Pharmacol. Ther. 21, 812-817. doi: 10.1016/j.pupt.2008.07.001

Janssens, A., and Voets, T. (2011). Ligand stoichiometry of the coldand menthol- activated channel TRPM8. J. Physiol. 15, 4827-4835. doi: 10.1113/jphysiol.2011.216523

Julius, D. (2013). TRP channels and pain. Annu. Rev. Cell Dev. Biol. 29, 355-384. doi: 10.1146/annurev-cellbio-101011-155833

Kabbani, N. (2013). Not so Cool? Menthol's discovered actions on the nicotinic receptor and its implications for nicotine addiction. Front. Pharmacol. 4:95. doi: 10.3389/fphar.2013.00095

Kamatou, G. P., Vermaak, I., Viljoen, A. M., and Lawrence, B. M. (2013). Menthol: a simple monoterpene with remarkable biological properties. Phytochemistry 96, 15-25. doi: 10.1016/j.phytochem.2013.08.005

Karashima, Y., Damann, N., Prenen, J., Talavera, K., Segal, A., Voets, T., et al. (2007). Bimodal action of menthol on the transient receptor potential channel TRPA1. J. Neurosci. 27, 9874-9884. doi: 10.1523/JNEUROSCI.2221-07.2007

Kawasaki, H., Mizuta, K., Fujita, T., and Kumamoto, E. (2013). Inhibition by menthol and its related chemicals of compound action potentials in frog sciatic nerves. Life Sci. 92, 359-367. doi: 10.1016/j.lfs.2013.01.012

Kim, H. J., Wie, J., So, I., Jung, M. H., Ha, K. T., and Kim, B. J. (2016). Menthol modulates pacemaker potentials through TRPA1 channels in cultured interstitial cells of cajal from murine small intestine. Cell Physiol. Biochem. 38, 1869-1882. doi: 10.1159/000445549

Kim, K. Y., Bang, S., Han, S., Nguyen, Y. H., Kang, T. M., Kang, K. W., et al. (2008). TRP-independent inhibition of the phospholipase C pathway by natural sensory ligands. Biochem. Biophys. Res. Commun. 370, 295-300. doi: 10.1016/j.bbrc.2008.03.077

Kim, S. H., Nam, J. H., Park, E. J., Kim, B. J., Kim, S. J., So, I., et al. (2009). Menthol regulates TRPM8-independent processes in PC-3 prostate cancer cells. Biochim. Biophys. Acta 1792, 33-38. doi: 10.1016/j.bbadis.2008.09.012

Klein, A. H., Sawyer, C. M., Carstens, M. I., Tsagareli, M. G., Tsiklauri, N., and Carstens, E. (2010). Topical application of L-menthol induces heat analgesia, mechanical allodynia, and a biphasic effect on cold sensitivity in rats. Behav. Brain Res. 212, 179-186. doi: 10.1016/j.bbr.2010.04.015

Klein, A. H., Sawyer, C. M., Takechi, K., Davoodi, A., Ivanov, M. A., Carstens, M. I., et al. (2012). Topical hindpaw application of Lmenthol decreases responsiveness to heat with biphasic effects on cold sensitivity of rat lumbar dorsal horn neurons. Neuroscience 219, 234-242. doi: 10.1016/j.neuroscience.2012.05.061

Lansdell, S. J., Sathyaprakash, C., Doward, A., and Millar, N. S. (2015). Activation of human 5-hydroxytryptamine type 3 receptors via an allosteric transmembrane site. Mol. Pharmacol. 87, 87-95. doi: 10.1124/mol.114.094540

Latorre, R., Morera, F. J., and Zaelzer, C. (2013). "Voltage-dependent $\mathrm{K}^{+}$channels," in Encyclopedia of Biological Chemistry, eds W. J. Lennarz and M. D. Lane (Waltham, MA: Academic Press), 555-559.

Latorre, R., Zaelzer, C., and Brauchi, S. (2009). Structure-functional intimacies of transient receptor potential channels. Q. Rev. Biophys. 42, 201-246. doi: 10.1017/S0033583509990072

Lau, B. K., Karim, S., Goodchild, A. K., Vaughan, C. W., and Drew, G. M. (2014). Menthol enhances phasic and tonic GABAA receptor-mediated currents in midbrain periaqueductal grey neurons. Br. J. Pharmacol. 171, 2803-2813. doi: 10.1111/bph.12602

Lee, A. G. (2011). Biological membranes: the importance of molecular detail. Trends. Biochem. Sci. 36, 493-500. doi: 10.1016/j.tibs.2011.06.007

Lee, M. H., Yeon, K. Y., Park, C. K., Li, H. Y., Fang, Z., Kim, M. S., et al. (2005). Eugenol inhibits calcium currents in dental afferent neurons. J. Dent. Res. 84, 848-851. doi: 10.1177/154405910508400913

Li, Q., Wang, X., Yang, Z., Wang, B., and Li, S. (2009). Menthol induces cell death via the TRPM8 channel in the human bladder cancer cell line T24. Oncology 77, 335-341. doi: 10.1159/000264627
Lu, H. F., Hsueh, S. C., Yu, F. S., Yang, J. S., Tang, N. Y., Chen, S. C., et al. (2006). The role of $\mathrm{Ca}^{2+}$ in (-)-menthol-induced human promyelocytic leukemia HL-60 cell death. In vivo 20, 69-75.

Lummis, S. C. (2012). 5-HT(3) receptors. J. Biol. Chem. 287, 40239-40245. doi: $10.1074 /$ jbc.R112.406496

Macpherson, L. J., Hwang, S. W., Miyamoto, T., Dubin, A. E., Patapoutian, A., and Story, G. M. (2006). More than cool: promiscuous relationships of menthol and other sensory compounds. Mol. Cell Neurosci. 32, 335-343. doi: 10.1016/j.mcn.2006.05.005

Mahieu, F., Owsianik, G., Verbert, L., Janssens, A., De Smedt, H., Nilius, B., et al. (2007). TRPM8-independent menthol-induced $\mathrm{Ca}^{2+}$ release from endoplasmic reticulum and Golgi. J. Biol. Chem. 282, 3325-3336. doi: 10.1074/jbc.M605213200

Maljevic, S., and Lerche, H. (2013). Potassium channels: a review of broadening therapeutic possibilities for neurological diseases. J. Neurol. 260, 2201-2211. doi: $10.1007 /$ s00415-012-6727-8

McKemy, D. D., Neuhausser, W. M., and Julius, D. (2002). Identification of a cold receptor reveals a general role for TRP channels in thermosensation. Nature 416, 52-58. doi: 10.1038/nature719

Melanaphy, D., Johnson, C. D., Kustov, M. V., Watson, C. A., Borysova, L., Burdyga, T. V., et al. (2016). Ion channel mechanisms of rat tail artery contraction-relaxation by menthol involving, respectively, TRPM8 activation and L-type $\mathrm{Ca}^{2+}$ channel inhibition. Am. J. Physiol. Heart. Circ. Physiol. 311, H1416-H1430. doi: 10.1152/ajpheart.002 22.2015

Moreau, A., Gosselin-Badaroudine, P., and Chahine, M. (2014). Biophysics, pathophysiology, and pharmacology of ion channel gating pores. Front. Pharmacol. 5:53. doi: 10.3389/fphar.2014.00053

Morenilla-Palao, C., Pertusa, M., Meseguer, V., Cabedo, H., and Viana, F. (2009). Lipid raft segregation modulates TRPM8 channel activity. J. Biol. Chem. 284, 9215-9224. doi: 10.1074/jbc.M807228200

Morise, M., Ito, Y., Matsuno, T., Hibino, Y., Mizutani, T., Ito, S., et al. (2010). Heterologous regulation of anion transporters by menthol in human airway epithelial cells. Eur. J. Pharmacol. 635, 204-211. doi: 10.1016/j.ejphar.2010.03.032

National Toxicology Program (1979). Bioassay of Dl-Menthol for Possible Carcinogenicity. Natl. Cancer Inst. Carcinog. Tech. Rep. Ser. 98, $1-131$.

Neumann, J. T., and Copello, J. A. (2011). Cross-reactivity of ryanodine receptors with plasma membrane ion channel modulators. Mol. Pharmacol. 80, 509-517. doi: $10.1124 / \mathrm{mol} .111 .071167$

Nilius, B., and Appendino, G. (2013). Spices: the savory and beneficial science of pungency. Rev. Physiol. Biochem. Pharmacol. 164, 1-76. doi: 10.1007/112_2013_11

Nilius, B., and Szallasi, A. (2014). Transient receptor potential channels as drug targets: from the science of basic research to the art of medicine. Pharmacol. Rev. 66, 676-814. doi: 10.1124/pr.113.008268

OECD (2003). OECD-Screening Information Dataset (SIDS) Initial Assessment Profile (2003.) Available online at: www.inchem.org/documents/sids/sids/ MENTHOLS.pdf.

Oz, M. (2006). Receptors-independent actions of cannabinoids on cell membranes: focus on endocannabinoids. Pharmacol. Ther. 111, 114-144. doi: 10.1016/j.pharmthera.2005.09.009

Oz, M., Lozon, Y., Sultan, A., Yang, K. H., and Galadari, S. (2015). Effects of monoterpenes on ion channels of excitable cells. Pharmacol. Ther. 152, 83-97. doi: 10.1016/j.pharmthera.2015.05.006

Palade, P. (1987). Drug-induced $\mathrm{Ca}^{2+}$ release from isolated sarcoplasmic reticulum. II. Releases involving a $\mathrm{Ca}^{2+}$-induced $\mathrm{Ca}^{2+}$ release channel. J. Biol. Chem. 262, 6142-6148.

Pan, R., Tian, Y., Gao, R., Li, H., Zhao, X., and Barrett, J. E. (2012). Central mechanisms of menthol-induced analgesia. J. Pharmacol. Exp. Ther. 343, 661-672. doi: 10.1124/jpet.112.196717

Patel, T., Ishiuji, Y., and Yosipovitch, G. (2007). Menthol: a refreshing look at this ancient compound. J. Am. Acad. Dermatol. 57, 873-878. doi: 10.1016/j.jaad.2007.04.008

Peier, A. M., Moqrich, A., Hergarden, A. C., Reeve, A. J., Andersson, D. A., Story, G. M., et al. (2002). A TRP channel that senses cold stimuli and menthol. Cell 108, 705-715. doi: 10.1016/S0092-8674(02)00652-9 
Pertusa, M., Madrid, R., Morenilla-Palao, C., Belmonte, C., and Viana, F. (2012). N-glycosylation of TRPM8 ion channels modulates temperature sensitivity of cold thermoreceptor neurons. J. Biol. Chem. 287, 18218-18229. doi: 10.1074/jbc.M111.312645

Peters, C. H., and Ruben, P. C. (2014). Introduction to sodium channels. Handb. Exp. Pharmacol. 221, 1-6. doi: 10.1007/978-3-642-41588-3_1

Pezzoli, M., Elhamdani, A., Camacho, S., Meystre, J., González, S. M., le Coutre, J., et al. (2014). Dampened neural activity and abolition of epileptic-like activity in cortical slices by active ingredients of spices. Sci. Rep. 4:6825. doi: $10.1038 /$ srep 06825

Poveda, J. A., Giudici, A. M., Renart, M. L., Molina, M. L., Montoya, E., Fernández-Carvajal, A., et al. (2014). Lipid modulation of ion channels through specific binding sites. Biochim. Biophys. Acta 1838, 1560-1567. doi: 10.1016/j.bbamem.2013.10.023

Ramos-Filho, A. C., Shah, A., Augusto, T. M., Barbosa, G. O., Leiria, L. O., de Carvalho, H. F., et al. (2014). Menthol inhibits detrusor contractility independently of TRPM8 activation. PLOS ONE 9:e111616. doi: 10.1371/journal.pone.0111616

Reiner, G. N., Labuckas, D. O., and García, D. A. (2009). Lipophilicity of some GABAergic phenols and related compounds determined by HPLC and partition coefficients in different systems. J. Pharm. Biomed. Anal. 49, 686-691. doi: 10.1016/j.jpba.2008.12.040

Reuter, H., Lennarz, W. J., and Lane, M. D. (2013). "Voltage-gated $\mathrm{Ca}^{2+}$ channels," in Encyclopedia of Biological Chemistry, (Waltham, MA: Academic Press), 560-563.

Romanelli, M. N., Gratteri, P., Guandalini, L., Martini, E., Bonaccini, C., and Gualtieri, F. (2007). Central nicotinic receptors: structure, function, ligands, and therapeutic potential. Chem. Med. Chem. 2, 746-767. doi: $10.1002 / \mathrm{cmdc} .200600207$

Ruskin, D. N., Anand, R., and LaHoste, G. J. (2008). Chronic menthol attenuates the effect of nicotine on body temperature in adolescent rats. Nicotine Tob. Res. 10, 1753-1759. doi: $10.1080 / 14622200802443734$

Ruta, V., and MacKinnon, R. (2004). Localization of the voltage-sensor toxin receptor on KvAP. Biochemistry 43, 10071-10079. doi: 10.1021/bi049463y

Sánchez, M. E., Turina, A. V., García, D. A., Nolan, M. V., and Perillo, M. A. (2004). Surface activity of thymol: implications for an eventual pharmacological activity. Colloids Surf. B. Biointerfaces 34, 77-86. doi: 10.1016/j.colsurfb.2003.11.007

Savio-Galimberti, E., Gollob, M. H., and Darbar, D. (2012). Voltage-gated sodium channels: biophysics, pharmacology, and related channelopathies. Front. Pharmacol. 3:124. doi: 10.3389/fphar.2012.00124

Sidell, N., Verity, M. A., and Nord, E. P. (1990). Menthol blocks dihydropyridineinsensitive $\mathrm{Ca}^{2+}$ channels and induces neurite outgrowth in human neuroblastoma cells. J. Cell Physiol. 142, 410-419. doi: 10.1002/jcp.1041420226

Sigel, E., and Steinmann, M. E. (2012). Structure, function, and modulation of GABA(A) receptors. J. Biol. Chem. 287, 40224-40231. doi: $10.1074 /$ jbc.R112.386664

Simms, B. A., and Zamponi, G. W. (2014). Neuronal voltage-gated calcium channels: structure, function, and dysfunction. Neuron 82, 24-45. doi: 10.1016/j.neuron.2014.03.016

Slominski, A. (2008). Cooling skin cancer: menthol inhibits melanoma growth. Focus on "TRPM8 activation suppresses cellular viability in human melanoma." Am. J. Physiol. Cell Physiol. 295, C293-C295. doi: 10.1152/ajpcell.00312.2008

Spichiger, M., Muhlbauer, R. C., and Brenneisen, R. (2004). Determination of menthol in plasma and urine of rats and humans by headspace solid phase microextraction and gas chromatography-mass spectrometry. J. Chromatogr. B. Analyt. Technol. Biomed. Life Sci. 799, 111-117. doi: 10.1016/j.jchromb.2003.10.022

Swandulla, D., Carbone, E., Schäfer, K., and Lux, H. D. (1987). Effect of menthol on two types of Ca currents in cultured sensory neurons of vertebrates. Pflugers Arch. 409, 52-59. doi: 10.1007/BF00584749

Swandulla, D., Schäfer, K., and Lux, H. D. (1986). Calcium channel current inactivation is selectively modulated by menthol. Neurosci. Lett. 68, 23-28. doi: 10.1016/0304-3940(86)90223-5

Takeuchi, S., Tamaoki, J., Kondo, M., and Konno, K. (1994). Effect of menthol on cytosolic $\mathrm{Ca}^{2+}$ levels in canine airway epithelium in culture. Biochem. Biophys. Res. Commun. 2001, 1333-1338. doi: 10.1006/bbrc.1994.1850
Tani, M., Onimaru, H., Ikeda, K., Kawakami, K., and Homma, I. (2010). Menthol inhibits the respiratory rhythm in brainstem preparations of the newborn rats. Neuroreport 21, 1095-1099. doi: 10.1097/WNR.0b013e3283405bad

Tian, C., Zhu, R., Zhu, L., Qiu, T., Cao, Z., and Kang, T. (2014). Potassium channels: structures, diseases, and modulators. Chem. Biol. Drug Des. 83, 1-26. doi: $10.1111 /$ cbdd.12237

Tien, J., Young, D. M., Jan, Y. N., and Jan, L. Y. (2014). "Chapter 11 - molecular properties of ion channels," in From Molecules to Networks, 3rd Edn, (Boston, MA: Academic Press), 323-348.

Ton, H. T., Smart, A. E., Aguilar, B. L., Olson, T. T., Kellar, K. J., and Ahern, G. P. (2015). Menthol enhances the desensitization of human a334 nicotinic acetylcholine receptors. Mol. Pharmacol. 88, 256-264. doi: $10.1124 / \mathrm{mol} .115 .098285$

Tong, F., and Coats, J. R. (2012). Quantitative structure-activity relationships of monoterpenoid binding activities to the housefly GABA receptor. Pest Manag. Sci. 68, 1122-1129. doi: 10.1002/ps.3280

Trudell, J. R., Messing, R. O., Mayfield, J., and Harris, R. A. (2014). Alcohol dependence: molecular and behavioral evidence. Trends Pharmacol. Sci. 35 317-323. doi: 10.1016/j.tips.2014.04.009

Tsuzuki, K., Xing, H., Ling, J., and Gu, J. G. (2004). Menthol-induced $\mathrm{Ca}^{2+}$ release from presynaptic $\mathrm{Ca}^{2+}$ stores potentiates sensory synaptic transmission. $J$. Neurosci. 24, 762-771. doi: 10.1523/JNEUROSCI.4658-03.2004

Turina, A. V., Nolan, M. V., Zygadlo, J. A., and Perillo, M. A. (2006). Natural terpenes: self-assembly and membrane partitioning. Biophys. Chem. 122, 101-113. doi: 10.1016/j.bpc.2006.02.007

Valiyaveetil, F. I., Zhou, Y., and MacKinnon, R. (2002). Lipids in the structure, folding, and function of the KcsA K ${ }^{+}$channel. Biochemistry 41, 10771-10777. doi: $10.1021 /$ bi026215y

Veldhuis, N. A., Poole, D. P., Grace, M., McIntyre, P., and Bunnett, N. W. (2015). The G protein-coupled receptor-transient receptor potential channel axis: molecular insights for targeting disorders of sensation and inflammation. Pharmacol. Rev. 67, 36-73. doi: 10.1124/pr.114.009555

Vetter, I., Hein, A., Sattler, S., Hessler, S., Touska, F., Bressan, E., et al. (2013). Amplified cold transduction in native nociceptors by M-channel inhibition. J. Neurosci. 33, 16627-16641. doi: 10.1523/JNEUROSCI.1473-13.2013

Vladymyrova, I. A., Filippov, I. B., Kuliieva, I. M., Iurkevych, A., Skryma, R., Prevarskaia, N., et al. (2011). Comparative effects of menthol and icilin on the induced contraction of the smooth muscles of the vas deferens of normal and castrated rats. Fiziol. Zh. 57, 21-33.

Voets, T., Droogmans, G., Wissenbach, U., Janssens, A., Flockerzi, V., and Nilius, B. (2004). The principle of temperature-dependent gating in cold- and heatsensitive TRP channels. Nature 430, 748-754. doi: 10.1038/nature02732

Voets, T., Owsianik, G., Janssens, A., Talavera, K., and Nilius, B. (2007). TRPM8 voltage sensor mutants reveal a mechanism for integrating thermal and chemical stimuli. Nat. Chem. Biol. 3, 174-182. doi: 10.1038/nchembio862

Vogt-Eisele, A. K., Weber, K., Sherkheli, M. A., Vielhaber, G., Panten, J., Gisselmann, G., et al. (2007). Monoterpenoid agonists of TRPV3. Br. Pharmacol. 151, 530-540 doi: 10.1038/sj.bjp.0707245

Walstab, J., Wohlfarth, C., Hovius, R., Schmitteckert, S., Röth, R., Lasitschka, F., et al. (2014). Natural compounds boldine and menthol are antagonists of human 5-HT3 receptors: implications for treating gastrointestinal disorders. Neurogastroenterol. Motil. 26, 810-820. doi: 10.1111/nmo.12334

Wang, H. W., Liu, S. C., Chao, P. Z., and Lee, F. P. (2016). Menthol inhibiting parasympathetic function of tracheal smooth muscle. Int. J. Med. Sci. 13, 923-928. doi: 10.7150/ijms.17042

Watt, E. E., Betts, B. A., Kotey, F. O., Humbert, D. J., Griffith, T. N., Kelly, E. W., et al. (2008). Menthol shares general anesthetic activity and sites of action on the GABAA receptor with the intravenous agent, propofol. Eur. J. Pharmacol, 590, 120-126. doi: 10.1016/j.ejphar.2008. 06.003

Wickham, R. J. (2015). How menthol alters tobacco-smoking behavior: a biological perspective. Yale J. Biol. Med. 88, 279-287.

Willis, D. N., Liu, B., Ha, M. A., Jordt, S. E., and Morris, J. B. (2011). Menthol attenuates respiratory irritation responses to multiple cigarette smoke irritants. FASEB J. 12, 4434-4444. doi: 10.1096/fj.11-188383

Wondergem, R., and Bartley, J. W. (2009). Menthol increases human glioblastoma intracellular $\mathrm{Ca}^{2+}$, BK channel activity and cell migration. J. Biomed. Sci. 16:90. doi: $10.1186 / 1423-0127-16-90$ 
Wright, C. E., Laude, E. A., Grattan, T. J., and Morice, A. H. (1997). Capsaicin and neurokinin A-induced bronchoconstriction in the anaesthetised guinea-pig: evidence for a direct action of menthol on isolated bronchial smooth muscle. Br. J. Pharmacol. 121, 1645-1650. doi: 10.1038/sj.bjp.0701319

Yamamura, H., Ugawa, S., Ueda, T., Morita, A., and Shimada, S. (2008). TRPM8 activation suppresses cellular viability in human melanoma. Am. J. Physiol. Cell. Physiol. 295, C296-C301. doi: 10.1152/ajpcell.00499.2007

Yevenes, G. E., and Zeilhofer, H. U. (2011). Allosteric modulation of glycine receptors. Br. J. Pharmacol. 164, 224-236. doi: 10.1111/j.1476-5381.2011. 01471.x

Zhang, X. B., Jiang, P., Gong, N., Hu, X. L., Fei, D., Xiong, Z. Q., et al. (2008). Atype GABA receptor as a central target of TRPM8 agonist menthol. PLoS ONE 3:e3386. doi: 10.1371/journal.pone.0003386

Ziemba, P. M., Schreiner, B. S., Flegel, C., Herbrechter, R., Stark, T. D., Hofmann, T., et al. (2015). Activation and modulation of recombinantly expressed serotonin receptor type $3 \mathrm{~A}$ by terpenes and pungent substances. Biochem. Biophys. Res. Commun. 467, 1090-1096. doi: 10.1016/j.bbrc.2015.09.074
Zunino, M. P., Turina, A. V., Zygadlo, J. A., and Perillo, M. A. (2011) Stereoselective effects of monoterpenes on the microviscosity and curvature of model membranes assessed by DPH steady-state fluorescence anisotropy and light scattering analysis. Chirality 23, 867-877. doi: 10.1002/chir. 20998

Conflict of Interest Statement: The authors declare that the research was conducted in the absence of any commercial or financial relationships that could be construed as a potential conflict of interest.

Copyright (C) 2017 Oz, El Nebrisi, Yang, Howarth and Al Kury. This is an openaccess article distributed under the terms of the Creative Commons Attribution License (CC BY). The use, distribution or reproduction in other forums is permitted, provided the original author(s) or licensor are credited and that the original publication in this journal is cited, in accordance with accepted academic practice. No use, distribution or reproduction is permitted which does not comply with these terms. 